\title{
Microbial glycoconjugates in organic pollutant bioremediation: recent advances and applications
}

\author{
Pankaj Bhatt ${ }^{1,2}$, Amit Verma ${ }^{3}$, Saurabh Gangola ${ }^{4}$, Geeta Bhandari ${ }^{5}$ and Shaohua Chen ${ }^{1,2^{*}}$ (i)
}

\begin{abstract}
The large-scale application of organic pollutants (OPs) has contaminated the air, soil, and water. Persistent OPs enter the food supply chain and create several hazardous effects on living systems. Thus, there is a need to manage the environmental levels of these toxicants. Microbial glycoconjugates pave the way for the enhanced degradation of these toxic pollutants from the environment. Microbial glycoconjugates increase the bioavailability of these OPs by reducing surface tension and creating a solvent interface. To date, very little emphasis has been given to the scope of glycoconjugates in the biodegradation of OPs. Glycoconjugates create a bridge between microbes and OPs, which helps to accelerate degradation through microbial metabolism. This review provides an in-depth overview of glycoconjugates, their role in biofilm formation, and their applications in the bioremediation of OP-contaminated environments.
\end{abstract}

Keywords: Glycoconjugates, Bioremediation, Biosurfactants, Organic pollutants, Biofilm

\section{Introduction}

Organic pollutants (OPs) are used in large quantities in the industrial and agricultural sectors [1]. The rapid industrialization and anthropogenic activities of the present era have increased environmental contamination with various OPs, including compounds like chloroform, benzene, carbon tetrachloride, paints, gasoline, adhesives, plastic compounds, chlorohydrocarbons ( $\mathrm{CHCs}$ ), and pesticides [2]. OPs are presently found in the air, soil, and water and have various adverse effects on living systems, including the flora and fauna present in the ecosystem [3]. These OPs are also reported to be responsible for various toxic effects in humans, including adverse carcinogenic, mutagenic, and teratogenic effects. Thus, remediation strategies for these OPs are essential in the

*Correspondence: shchen@scau.edu.cn

${ }^{2}$ Guangdong Province Key Laboratory of Microbial Signals and Disease Control, South China Agricultural University, Guangzhou 510642, China

Full list of author information is available at the end of the article present scenario (Fig. 1). The remediation of OPs usually uses physical and chemical techniques such as soil washing, pumping, aeration, oxidation, incineration, etc. [4]. However, these methods have many disadvantages and usually result in secondary environmental contamination; they are also uneconomical to use. The secondary contaminants are not emitted directly from the source they formed due to degradation reactions of the main pollutants. Therefore, bioremediation strategies utilizing living systems are the only hope for the eco-friendly management of these OPs.

Microbial bioremediation (MB) is usually considered one of the best methods for the treatment of environmental contamination. The rich diversity of metabolizing enzymes participated in the bioremediation processes [3]. The MB of contaminants is possible through enzymatic reactions, which produce different intermediate metabolites through metabolic pathways. Although single microbial cultures have been used as potent contaminant degraders in recent decades, but mixed cultures 


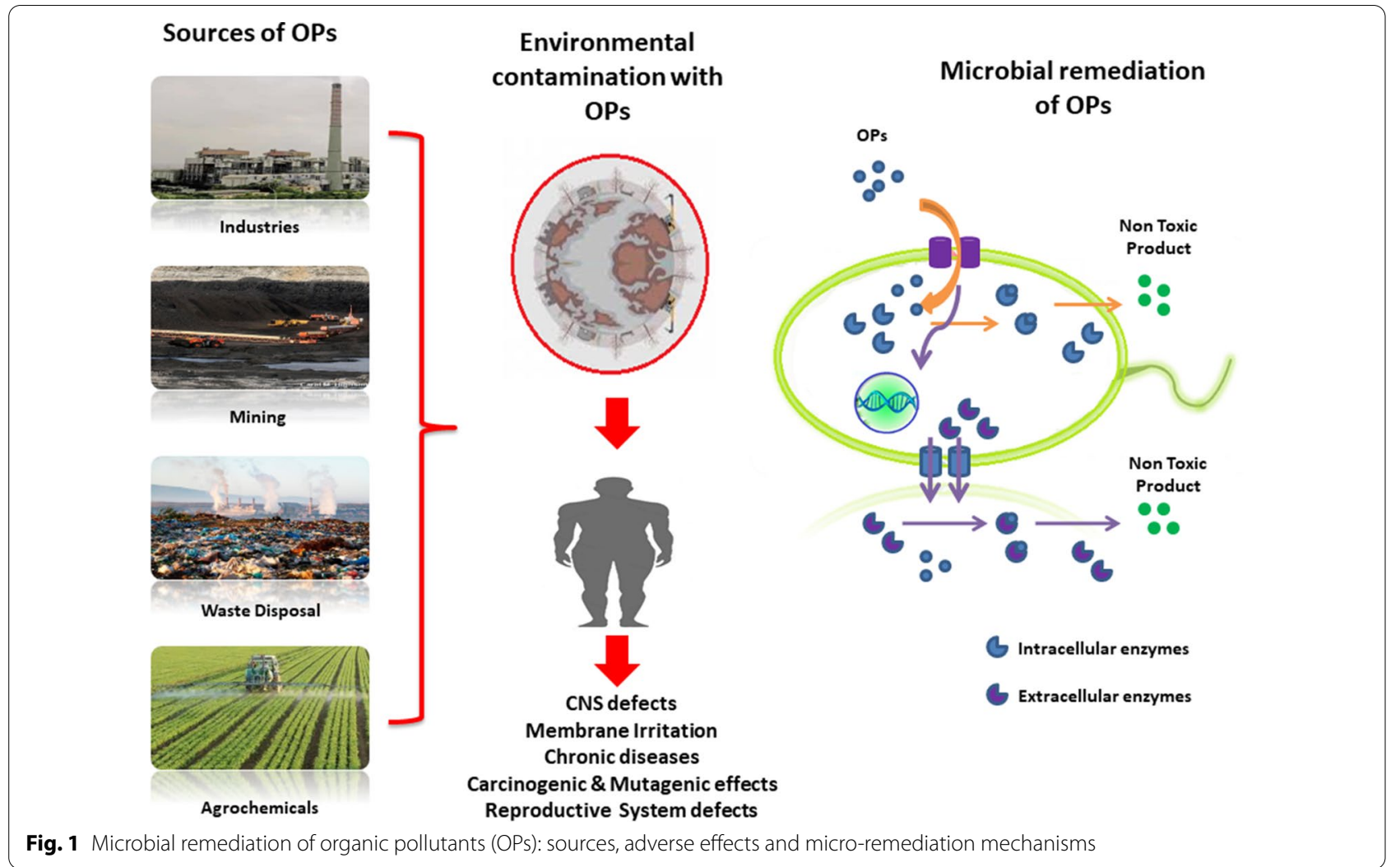

perform better in environments [5]. Environmental contamination with OPs can be managed by utilizing microbial metabolic processes that degrade these OPs into non-toxic metabolites in an economical, eco-friendly, and efficient manner [6]. Thus, researchers are involved in the study of microbial biodegradation mechanisms related to OPs to develop low cost and simple techniques for the management of these pollutants. OPs are metabolized by microbial cells using both aerobic and anaerobic metabolism. Anaerobic metabolism is one of the most preferred methods in bioremediation, especially for chlorinated OPs. However, sometimes OPs involve the production of much more toxic compounds, such as trichloroethylene (TCE). Microbial degradation via anaerobic mechanisms results in the production of dichloroethylene (DCE) and vinyl chlorides (VCs), which have higher environmental toxicity than their parent compound, TCE [2]. Thus, at times, aerobes are the best choice for OP bioremediation due to presence of various catabolite enzymes with broad specificity to degrade different types of OPs. These aerobes consist of various oxygenases that play a significant role in the degradation of pollutants from contaminated sites. For example, Pseudomonas sp. has oxygenases that can metabolize TCE along with the associated DCE and VCs into $\mathrm{CO}_{2}$ and $\mathrm{Cl}^{-}$, where both the final products are non-toxic [4]. However, the efficient degradation of OPs rests in understanding its transportation inside the microbial cell and its assimilation. Studies indicate that microbial glycolipids and other glycoconjugates play a very important role in the mechanism of transport of these OPs across microbial membranes [7]. These microbial glycol compounds act as emulsifiers and are called "biosurfactants", which are located either inside the cell or secreted outside and help in the bioremediation mechanism [8]. This gave rise to the term "microbial glycobiotechnology" (MG), which involves a wide array of methods, with the main goal of decontaminating different types of pollutants.

MG utilizes natural microbial resources for the transformation of the contaminated environment to a safe native natural form. MG involves the microbial production of carbohydrate polymeric compounds with novel applications in the field of bioremediation and waste management. Studies proved that biosurfactant production has a direct correlation to OP degradation. Thus, MG is gaining importance for the management of OPs in the environment [9]. MG interacts with proteins and metabolites and facilitates the degradation of OPs [10]. This review presents an overview of recent advances in MG and its specific applications in the bioremediation of different types of OPs. 


\section{Microbial glycoconjugates: types and application in bioremediation}

Glycobiotechnology, involves the transfer of the basic knowledge structure and functional relationship of glycoconjugates to practice-related synthetic and applied producers [11]. The term "glycoconjugate" indicates the combination of glycoproteins and glycolipids. Microbial strains are able to produce glycoconjugates and facilitate their metabolism in various ways, such as via the producers of these molecules, uptake of the desirable pollutants, and other substrates (Table 1).
Glycoconjugates are an integral part of the bacterial cell membrane, which consists of special types, viz., surface molecules (lipopolysaccharides, capsular polysaccharides, lipo-oligosaccharides, and glycoproteins), cellwall polymers, and secreted exopolysaccharides [12] (Fig. 2). In addition to this, microbial strains produce extracellular glycoconjugates such as rhamnolipids, sophorolipids and exopolysaccharides, glycoproteins, and glycol-lipopeptides. These glycoconjugates play a crucial role in the bioremediation of the OPs [13].

Table 1 Glycoconjugates in the bioremediation of organic pollutants (OPs)

\begin{tabular}{|c|c|c|c|c|}
\hline Microbial strains & Glycoconjugates & Organic pollutants & Mode of action & References \\
\hline Acinetobacter sp. Y1 & $\begin{array}{l}\text { Methyl hexadcanoate, methyl } \\
\text { octadecanoate }\end{array}$ & Petroleum hydrocarbon & $\begin{array}{l}\text { Reduce surface tension of water, } \\
\text { showed strong tolerance with } \\
\text { pH, temperature, salinity }\end{array}$ & [14] \\
\hline Pseudomonas, Rhodococcus & Biosurfactants & Cypermethrin & Emulsion reaction & [15] \\
\hline Achromobacter sp. A-8 & Biosurfactants & Crude oil & Reduce surface tension & [16] \\
\hline Acinetobacter baumannii BJ5 & Glycolipid biosurfactant & Pyrene & Growth linked production & {$[17]$} \\
\hline Burkholderia cenocepacia BSP3 & Glucolipid & $\begin{array}{l}\text { Methyl parathion, ethyl para- } \\
\text { thion, trifluralin }\end{array}$ & $\begin{array}{l}\text { Critical micelle formation (CMC) } \\
\text { and reducing surface tension }\end{array}$ & [18] \\
\hline Pseudomonas aeruginosa WH-1 & Biosurfactants & Hexachlorocyclohexane $(\mathrm{HCH})$ & $\begin{array}{l}\text { Lower the emulsification with } \\
\text { HCH }\end{array}$ & [19] \\
\hline Pseudomonas sp. & Rhamnolipids & Chlorpyrifos & $\begin{array}{l}\text { Increase the aqueous partition } \\
\text { and chlorpyrifos degradation }\end{array}$ & [20] \\
\hline Bacillus subtilis MTCC 1427 & Biosurfactants & Endosulfan & $\begin{array}{l}\text { Increase bioavailability of } \\
\text { endosulfan }\end{array}$ & [21] \\
\hline $\begin{array}{l}\text { Pseudomonas aeruginosa B1, P. } \\
\text { fluorescens B5, P. stutzeri B11 } \\
\text { and P.putida B15 }\end{array}$ & Exopolysaccharides (EPS) & $\begin{array}{l}\text { 2,4-D, benzene, toluene, xylene } \\
\text { and gasoline }\end{array}$ & $\begin{array}{l}\text { Organic pollutants affect EPS } \\
\text { production }\end{array}$ & {$[22]$} \\
\hline Penicillium simplicissimum & Tea saponin, rhamnolipid & Phenol & $\begin{array}{l}\text { CMC, reduce surface tension } \\
\text { and increase laccase produc- } \\
\text { tion }\end{array}$ & [23] \\
\hline Pseudomonas aeruginosa $\mathrm{CH} 7$ & Rhamnolipid & $\beta$-Cypermethrin & $\begin{array}{l}\text { Rhamnolipid promote the disso- } \\
\text { lution, absorption, adsorption }\end{array}$ & [24] \\
\hline $\begin{array}{l}\text { Candia, Pseudomonas, Deinococ- } \\
\text { cus, Nocardiopsis, Serratia }\end{array}$ & $\begin{array}{l}\text { Rhamnolipids, trehalolipids, } \\
\text { mannosylerythritol lipids, cel- } \\
\text { lobiose lipids }\end{array}$ & Organic pollutants & $\begin{array}{l}\text { Bioremediation of the organic } \\
\text { pollutants }\end{array}$ & {$[25]$} \\
\hline Pseudomonas, Bacillus, Candida & Rhamnolipid & Oil spill & $\begin{array}{l}\text { Reduce interfacial tension, } \\
\text { disperse oil particles }\end{array}$ & [26] \\
\hline $\begin{array}{l}\text { Pseudomonas aeruginosa, Rhodo- } \\
\text { coccus sp., Bacillus licheniformis, } \\
\text { Serratia marcescens, P. floures- } \\
\text { cens, B. subtilis }\end{array}$ & $\begin{array}{l}\text { Rhamnolipid, trehalolipid, } \\
\text { sophorolipid, peptide lipid, } \\
\text { serrawetin, visconsin, surfactin, } \\
\text { emulsan, liposan }\end{array}$ & Oil pollution & Enhanced degradation & {$[27]$} \\
\hline Serratia marcescens UCP 1549 & Lipoprotein, carbohydrate & Organic pollutants & $\begin{array}{l}\text { Agricultural and marine biore- } \\
\text { mediation }\end{array}$ & {$[28]$} \\
\hline Bacillus subtilis B20 & Biosurfactants & Oil rock & $\begin{array}{l}\text { Reduced surface and interfacial } \\
\text { tension }\end{array}$ & [29] \\
\hline Paenibacillus sp. D9 & Lipopeptide biosurfactant & Hydrocarbons & $\begin{array}{l}\text { Enhanced biodegradation of } \\
\text { hydrophobic pollutants }\end{array}$ & {$[30]$} \\
\hline $\begin{array}{l}\text { Bacillus, Rhodococcus, Actinomy- } \\
\text { cetes, Pseudomonas }\end{array}$ & $\begin{array}{l}\text { Lipopeptide, glycolipid, } \\
\text { sophorolipds }\end{array}$ & Organic pollutants & $\begin{array}{l}\text { Reduce surface tension with } \\
\text { higher degradation }\end{array}$ & [31] \\
\hline $\begin{array}{l}\text { Bacillus algicola, Rhodococcus soli, } \\
\text { Isoptericola chiayiensis, Pseu- } \\
\text { doalteromonas agarivorans }\end{array}$ & Rhamnolipids & Crude oil & Low surface tension & {$[32]$} \\
\hline
\end{tabular}



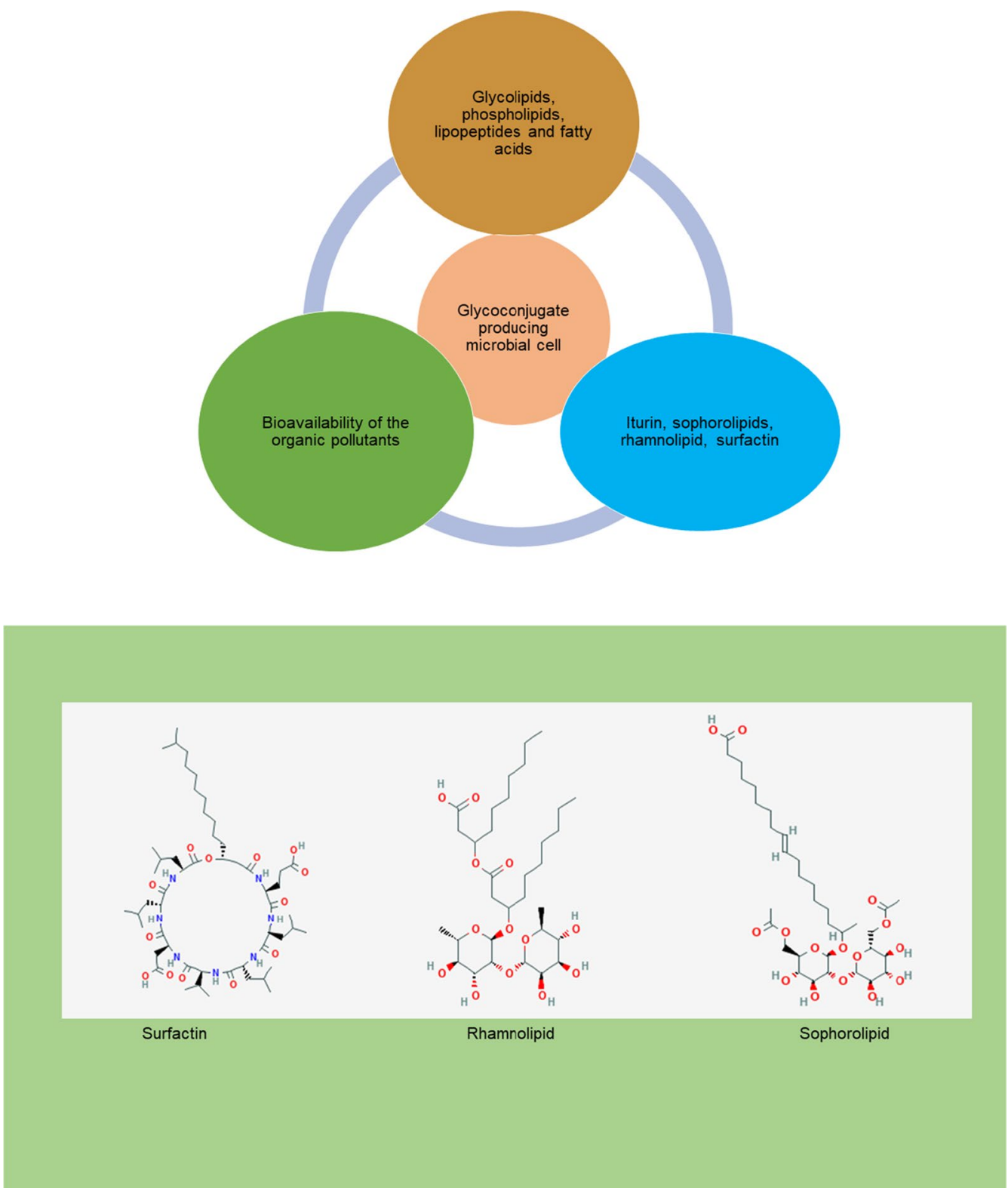

Fig. 2 Microbial glycoconjugates in the bioremediation of organic pollutants (OPs)

Microorganisms produce glycoconjugates with biosurfactant properties during the stationary phase of the microbial growth cycle [33, 34]. Glycoconjugates are amphiphilic compounds synthesized onto the cell surface of the microorganism [35]. These molecules contain hydrophilic and hydrophobic moieties that reduce the surface and interfacial tension. Glycoconjugates can have diverse structures, such as glycoproteins, glycopeptides, peptidoglycans, glycolipids, lipopolysaccharides, and glycosides. The production of the glycoconjugates depends on the producer microorganism, nutritional sources such as carbon and nitrogen, trace elements, and the physicochemical conditions for production. Recently, glycoconjugate rhamnolipids have been the most commonly used in industrial and environmental applications [35, 36]. The glycolipid rhamnolipid is well studied in the Pseudomonas and Burkholderia species [36]. Pseudomonas aeruginosa is considered as the top rhamnolipid producer at over $100 \mathrm{~g} \cdot \mathrm{L}^{-1}$. In a liquid culture, Pseudomonas aeruginosa produces two types of rhamnolipids referred to as mono and dirhamnolipid [35]. These molecules are synthesized by two enzyme-specific rhamnosyl transfer 
reactions. The enzyme that catalyzes these reactions is called rhamnosyltransferase [37, 38]. The hydrophobic and hydrophilic parts of the rhamnolipid are synthesized by different biosynthetic reactions in the microbial strains. After their synthesis, both of the portions are linked to each other, forming monorhamnolipids and dirhamnolipids. Yeasts are also reported to produce glycoconjugates such as sophorolipids, mannosylerythritol, cellobiose, and trehalose lipids. These have been explored for their greater potential in the bioremediation of polluted sites [39]. The enhanced bioremediation of pyrene and tetracycline in soil was investigated with the addition of sophorolipid [40].

Hydrophobic pollutants require desorption from the soil and water environment before microbial metabolism. Mineralization of OPs is governed by desorption from the soil. The application of glycoconjugates as biosurfactants for the bioremediation of environmental OPs is also well established; they play a direct role in the desorption of pollutants [41]. In the first step, these glycoconjugates interact with less soluble OPs and improve their transfer into the soil matrix and their subsequent removal [42]. In the second step, glycoconjugates act as a bridge between the microbial strains and soil, due to which the bioavailability of the pollutants increases [43, 44]. The increased concentrations of these surface-active glycoconjugate compounds help in the attachment of microbial cells to pollutants [45]. Biosurfactants increase the surface areas of hydrophobic pollutants through which their solubility increases in the soil and water environment. The use of biosurfactants for the biodegradation of pesticides has gained attention in recent years. Previous reports supported the role of biosurfactants in the bioremediation of hydrocarbon and pesticide-contaminated soil. These reports favor pesticide degradation using glycoconjugated biosurfactant usually synthesized from bacterial species viz., B. pumilus, B. mojavensis, B. licheniformis and B. amyloliquifaciens [46]. Biosurfactants of Lactobacillus pentosus degrade octane efficiently [47]. In a study, Burkholderia species isolated from an oil-contaminated area was able to produce biosurfactant, that plays a critical role in pesticide degradation [18, 48]. Biosurfactants that degrade naturally are ideally suitable for the removal of organic pollutants from the environment and considered ecofriendly to nature [49]. Previous studies indicated that the efficiency of OP degradation was improved in the presence of microbial glycoconjugates. Stimulation in the degradation of OPs was mainly due to the action of the biosurfactants. Enhancement in the degradation of octane was due to the biosurfactants production using Lactobacillus pentosus [47]. In addition to mobilization, glycoconjugated biosurfactants increase the degradation rate via other mechanisms [50]. An axenic culture of
Pseudomonas putida DOT-T1E produced a rhamnolipid that facilitated the bioremediation of chlorinated phenols. The logic behind this mechanism involves entrapment of the chlorophenol in the biosurfactant micelles and the hydrophobic relationship between these two types of compounds [51, 52]. Similarly, Actinobacteria produced biosurfactants that enhanced the rate of xenobiotics bioremediation [53]. Rhamnolipids were found to be adequate in the bioremediation of carbendazim with Rhodococcus sp. D-1 [54]. The rhamnolipid affected carbendazim degradation in a concentration-dependent manner with maximum bioremediation efficiency. It facilitated carbendazim emulsification and favorable changes on the cell surface, allowing it to enter Rhodococcus sp. D1 cells, and degradation subsequently occurred [54]. The glycolipid produced from the Rhodococcus sp. strain IITRO3 also makes the greater impact on degradation of 1,1,1-trichloro-2,2-bis (4-chlorophenyl) ethane [55]. The distribution of glycoconjugate-producing bacteria was reported in contaminated arid southwestern soil [56]. Rhizospheric microbes play an important role in the degradation of soil contamination, enhancing the degradation found with production of the glycoconjugates [57].

Another important concern is the effect of glycoconjugate biosurfactants on the candidate microbial strains that degrade OPs. The contrasting strains of P. aeruginosa produce glycoconjugate biosurfactants that enhance solubility and metabolism [58]. The purified biosurfactants cause an increase in the solubility of pyrene and higher solubilization of fluorene. The concentration of the biosurfactants is also very important for microbial growth. A higher concentration of these glycoconjugates inhibits the growth of microbial cells and reduces biodegradation potential [59]. These reports are not same for all the microbial strains, however, sometimes, a low concentration of glycoconjugate biosurfactants might also be toxic and show an antimicrobial effect $[60,61]$. Most biodegradation of OPs has been reported previously with axenic microbial strains, whereas for the consortium, more biodegradation was achieved. The glycoconjugates increased the rate of OP degradation with a microbial consortium due to cumulative effect of microbial communities [62]. In a study a seawater $B$. methylotrophicus produced glycoconjugate biosurfactants that reduce surface tension, can be used for bioremediation purposes [63]. Microbial rhamnolipids and surfactin are used by researchers for the bioremediation of organic pollutants in last decades $[64,65]$. The advantage of biosurfactants over synthetic surfactants is that the former induces low toxicity and stability in the presence of high temperature, high $\mathrm{pH}$, and saline environment [66]. Natural glycoconjugate surfactants play a role in sustainable development and bioremediation [67]. 
Substrates containing the rich carbohydrates and lipids have been recommended for large-scale microbial glycoconjugate production [65]. The most commonly used substrates viz., corn liquor, glycerol, soybean oil, animal fat, vegetable fat, and molasses [68-72]. The previous study concluded that agro-industrial waste can also be used for microbial glycoconjugate production [73]. These carbohydrate- and lipid-containing compounds are metabolized by microbial metabolic pathways and converted into glycoconjugates such as rhamnolipid. The choice of substrate for microbial growth determines the amount of glycoconjugate production. Microbes are able to produce glycoconjugates from all types of carbon sources, but to achieve higher production, soybeans, corn, canola, and olives can be used (Table 2). Glycoconjugates are considered secondary metabolites due to their production in the stationary phase of microbial growth [37].

\section{Glycoconjugates in action: overview of biofilm formation}

In recent years, researchers have taken great interest in the biofilm-based degradation of environmental contaminants. Microbial glycoconjugates also play an important role in biofilm formation and accelerate the bioremediation of the organic pollutants. Generally, under laboratory conditions, a single microbial strain is isolated to test its biodegradation potential for environmental contaminants. However, the basic facts of the environmental interactions between the chosen microbial cell and other microbial communities, or the nature of their habitats, are ignored $[100,101]$. Therefore, to harness the potential of microbial cells for glycoconjugate production and impact on biodegradation, it is necessary to consider the behavior of microbial communities and their habitats, even though the experiment was performed under laboratory conditions [5]. In nature, microbes interact with abiotic and biotic factors and produced the glycoconjugates. To maintain their populations via different types of interactions such as synergistic and antagonistic effects that allow microbes to adapt to different environmental conditions at polluted sites. Microbial communities consist of various microbial species that produced the glycoconjugate surfactants which have greater potential than a single culture glycoconjugates because the number of reporting genes and the diversity of metabolic activities work together and provide the maximum output within the shortest period [102]. So, the glycoconjugates produced by various microbial communities showed the cumulative effect on the degradation of the OPs. Importantly, the many microorganisms and microbial species present in microbial "biofilm" can degrade the wide range of contaminants present in the natural environment and engineered systems. Biofilm refers to a group of diverse microbial species attached to any living or nonliving surface and covered by a surrounding self-synthesized glycoconjugates, matrix comprising extracellular DNA, proteins, and water [103, 104]. Biofilm aids in the consumption of nutrients and oxygen, with tolerance against harsh environmental conditions during the bioremediation process. Biofilm based remediation technology is more cost-effective, ecofriendly, and easy for removing pollutants from the natural environment. Due to the production of glycoconjugates microbial biofilm absorbs and immobilizes environmental pollution, and the labor of gene expression divided among the existing microbial communities ultimately works very efficiently as a single unit. The various microbial communities within the biofilm are also responsible for differential gene expression of the substrate, showing a broad range of metabolic pathways for biodegradation. The most important characteristics of biofilm are their chemotaxis and flagellarbased movement. Biofilm can sense the presence of xenobiotics in their proximity and move towards them by swimming, swarming, and twitching, as well as by quorum sensing, which improves biodegradation in presence of glycoconjugates $[105,106]$. The composition of microbial biofilm depends on the environmental conditions in which the microbes reside [107-109]. Biofilm provides better environmental conditions and protection from environmental stress, acid stress, antimicrobial stress, UV stress, desiccation, predation, biocides, solvent, toxic chemicals, and other pollutants [110, 111]. Microbial biofilms are increasingly used as indicator systems for monitoring heavy metal contamination in water resources. Changes in the morphology of biofilms and their physiology indicate the occurrence of contaminants in their proximity. Biofilm is frequently found in different geographical locations, such as streambeds, tidal flats, corroded pipes, and sites of infection [112-114].

Microbes are able to communicate with each other in the form of communities and biofilms. The main mechanism behind biofilm formation is quorum sensing. In addition to playing various other roles, glycoconjugates help microbial cells to attach to one another in a biofilm [27]. Glycoconjugates create a favorable environment for the biodegradation of the OPs at the contaminated sites. Microbial cells produce an extracellular matrix that helps the cells attach to each other in communities. Glycoconjugates also help the microbes survive under extreme conditions and protect the microbial cells from the outer environment, especially under water stress conditions. The adhesion of the bacterial cells occurs in both the mobile and stagnant phases. These glycoconjugates are useful for floating the bacterial cells in water bodies as a biofilm, which can be efficiently utilized for bioremediation in water systems. 
Table 2 Glycoconjugates producing microorganisms and the associated techniques

\begin{tabular}{|c|c|c|c|c|}
\hline Microorganisms & Nature of glycoconjugates & Types of glycoconjugates & Techniques used for identification & References \\
\hline Pseudomonas aeruginosa MA01 & Glycolipid & Monorhamnolipid, dirhamnolipid & $\begin{array}{l}\text { Fourier transform infrared } \\
\text { spectroscopy (FTIR), thin layer } \\
\text { chromatography (TLC) }\end{array}$ & [74] \\
\hline Acinetobacter baumannii & Glycolipid & Palmitic and phthalic acid & $\begin{array}{l}\text { FTIR, gas chromatography and } \\
\text { masss pectrometry (GC-MS), } \\
\text { nuclear magnetic resonance } \\
\text { (NMR) }\end{array}$ & [17] \\
\hline Pseudomonas aeruginosa PG1 & Glycolipid & $\begin{array}{l}\text { Mono and di rhamnolipid con- } \\
\text { geners }\end{array}$ & $\begin{array}{l}\text { FTIR, liquid chromatography-mass } \\
\text { spectrometry (LC-MS), and } \\
\text { scanning electron microscope- } \\
\text { energy dispersive spectrometer } \\
\text { (SEM-EDS) }\end{array}$ & {$[9]$} \\
\hline Pseudomonas sp. & Glycolipid & Rhamnolipid & FTIR spectra analysis & [75] \\
\hline Pseudoxanthomonas sp. G3 & Glycolipid & Rhamnolipid type & FTIR spectra analysis & [76] \\
\hline Lactobacillus casei & Glycoprotein & Glycoprotein & FTIR and NuPAGE method & [77] \\
\hline Vibrio sp. 3B-2 & Glycoprotein & Glycoprotein & $\begin{array}{l}\text { Chemical method, spectrometric } \\
\text { characterization }\end{array}$ & [78] \\
\hline Candida bombicola ATCC 22,214 & Glycolipid & Sophorolipid & $\begin{array}{l}\text { NMR, high performance thin layer } \\
\text { chromatography (HPTLC) and } \\
\text { MALDI ToF MS }\end{array}$ & [79] \\
\hline Starmerella bombicola & Glycolipid & Sophorolipid & FTIR & [80] \\
\hline Rhodococcus sp. PML026 & Glycolipid & Trehalolipids & LC-MS & [81] \\
\hline Rhodococcus sp. PML026 & Glycolipid & Trehalolipids & Chemical analysis & [82] \\
\hline Cryptococcus Humicola JCM 1461 & Glycolipid & Cellobiose lipid & Chemical analysis & [83] \\
\hline Streptomyces sp. DPUA 1559 & Glycoprotein & Low mol. wt. glycoprotein & Electrophoretic analysis & [84] \\
\hline Ochrobactrum anthropi HM-1 & Glycolipid & Rhamnolipid type & TLC and FTIR spectra analysis & [85] \\
\hline Citrobacter freundii $\mathrm{HM}-2$ & Glycolipid & Rhamnolipid type & TLC and FTIR spectra analysis & [85] \\
\hline Lactobacillus & Glycoprotein & -- & TLC and FTIR & [86] \\
\hline Pseudomonas isolate DYNA270 & Glycolipid & Rhamnolipids & Mass spectrometry & [87] \\
\hline $\begin{array}{l}\text { Streptomyces nocardiopsis A17, } \\
\text { Bacillus subtilis ICA56 }\end{array}$ & Glycerol & Biosurfactant & TLC and LC-MS & [88] \\
\hline Bacillus psudomycoides BS6 & Lipopeptide & $\begin{array}{l}\text { Fatty acid 3-OH and peptide of } \\
\text { five amino acid }\end{array}$ & TLC and FTIR & [89] \\
\hline Bacillus subtilis B2O, B. subtilis B30 & Glycolipopeptide & Surfactin & $\begin{array}{l}\text { Pedant drop method, Lyophiliza- } \\
\text { tion }\end{array}$ & [29] \\
\hline Pseudomonas aeruginosa & Glycolipid & Rhamnolipid & & [90] \\
\hline P. aeruginosa MA01 & Glycolipid & Monorhamnolipid & $\begin{array}{l}\text { FTIR, electrospray ionization mass } \\
\text { spectrometry (ESI-MS) }\end{array}$ & [74] \\
\hline Klebsiella pneumonae WME02 & Phospholipid & biosurfactant & Biochemical characterization & [91] \\
\hline $\begin{array}{l}\text { Pseudomonas aeruginosa DS10- } \\
129\end{array}$ & Glycolipid & Rhamnolipid & Mass spectrometry & [92] \\
\hline Candia lipolytica IA 1055 & Glycolipid & Sophorolipid & $\begin{array}{l}\text { Emulsification, spectrophotom- } \\
\text { eter }\end{array}$ & [93] \\
\hline Pseudomonas aeruginosa & Glycolipid & Rhamnolipid & Spectrophotometer & [94] \\
\hline Serratia marcescens UCP 1549 & Glycolipid & Biosurfactant & Emulsification & [95] \\
\hline Bacillus subtilis & Glycolipopeptide & Cyclic lipopeptide biosurfactant & $\begin{array}{l}\text { High performance liquid chroma- } \\
\text { tography (HPLC), emulsification }\end{array}$ & {$[96,97]$} \\
\hline Candia lipolytica UCP0988 & Glycolipid & Sophorolipids & TLC, HPLC-ESI-MS & [90] \\
\hline $\begin{array}{l}\text { Marinobacter hydrocarbonoclasti- } \\
\text { cus SdK644 }\end{array}$ & Glycolipid & Biosurfactant & GC-MS, FTIR & [98] \\
\hline Paenibacillus sp. D9 & Glycolipopeptide & Biosurfactant & Emulsification & {$[31,97]$} \\
\hline Pseudozyma aphidis ZJUDM34 & Glycolipid & Mannosylerythritol lipids & TLC, GC-MS & [99] \\
\hline Bacillus subtilis, Paenibacillus sp. D9 & Glycolipopeptide & Surface active biosurfactant & $\begin{array}{l}\text { Gene cloning and expression, } \\
\text { affinity chromatography }\end{array}$ & {$[30,97]$} \\
\hline
\end{tabular}


The critical factor of biofilm formation is the production of the glycoconjugate biosurfactant, smoothness at the cell surface, the velocity of flow, and bacterial growth [115]. Biofilm formation is governed by several signaling molecules and glycoconjugates. Naturally, biofilm formation is a complex process that involves many steps. Preliminary bacterial cells produce extracellular polymeric substances (EPSs). These substances act as cementing material on the outer cell membrane and help in the entrapment of nutrients. In addition, EPS also has surfactant properties that help in the mineralization of xenobiotic compounds that are otherwise inaccessible. The production of EPS and water form a slimy layer in biofilms. Microbes also engage in symbiotic relationships with each other at the polluted sites (Fig. 3). The intermediate metabolites produced by primary bacterial colonizers can be used by the secondary colonizers that ultimately form the biofilm. The quorum sensing (QS) mechanisms are well-established for these biofilms and help in regulating EPS production [116]. The QS system can help microbes survive in the presence of stress, such as antimicrobial compounds, nutrient limiting conditions, and OPs. Microbial strains degrade toxic chemicals through the establishment of cellular communications with each other [117].

Glycoconjugates also play an important role in aggregation of the microbial cells in communities. The aggregation of microbial cells is an essential factor in biofilm formation $[118,119]$. Bacterial cells from two types of aggregation: auto and coaggregation. In auto-aggregation, genetically identical bacterial cells remain together, whereas coaggregation refers to genetically different cells [120]. The surface factors, extracellular polymeric substances, and diffusible signal molecules are critical factors involved in the auto-aggregation and microbial biofilm at polluted sites [121]. Aggregation also depends on microbial interactions such as antagonism, synergism, mutualism, competition, and commensalism [122].

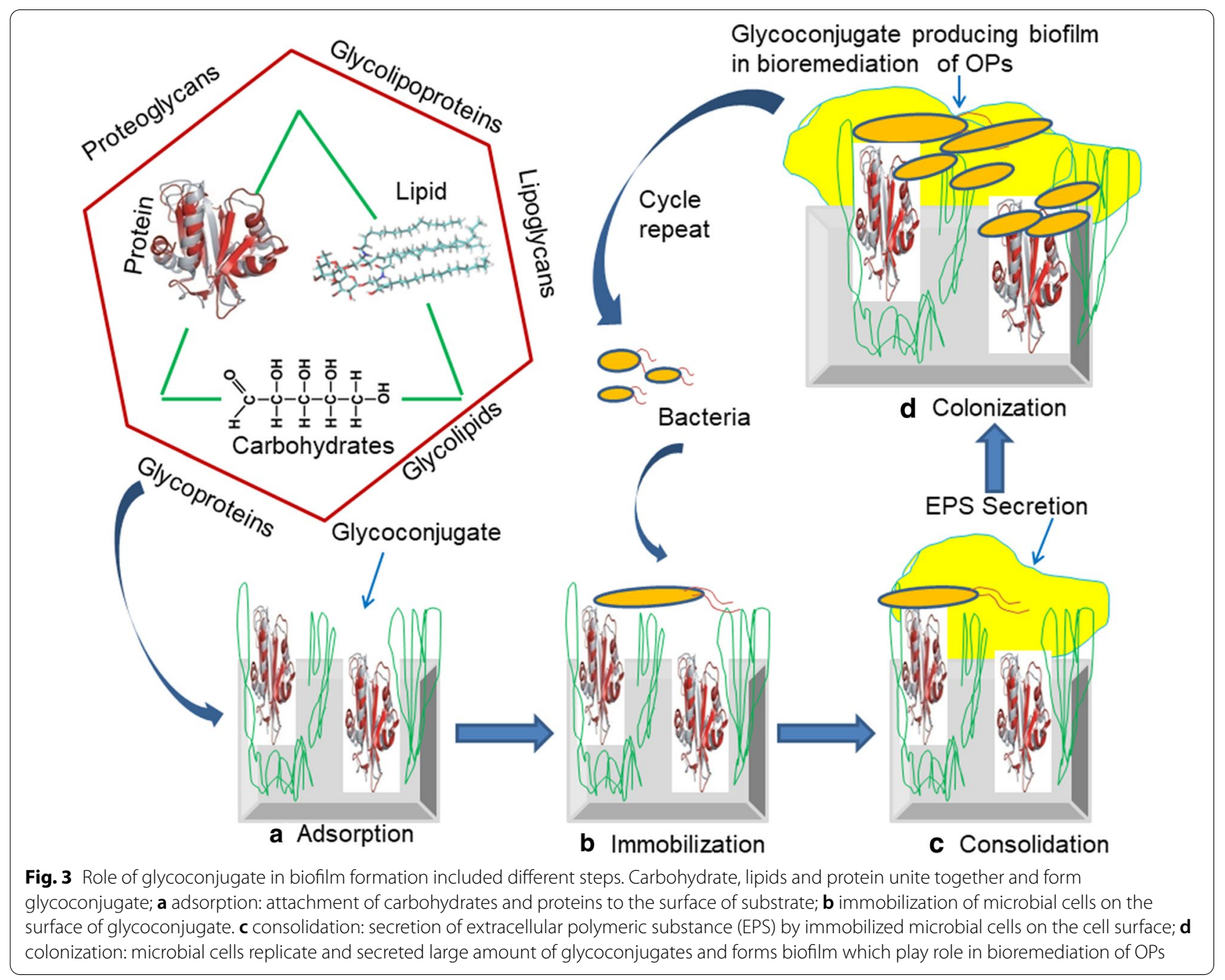


Several in-vitro and in-situ studies based on biofilm have been conducted in recent decades in the field of bioremediation with glycoconjugates. In-situ biofilm mediated bioremediation can be performed in several ways. In nature, certain contaminants are degraded, transferred, and immobilized under specific environmental conditions without any interference of human activity [123]. Naturally, the biodegradation process requires the availability of the microorganism in the form of biofilm at polluted site and requires a long period of time. The addition of extra nutrients such as carbon, hydrogen, nitrogen, phosphorous, and oxygen to increase the growth rate of the microbial population enhances the degradation rate of pollutants [123, 124].

Biofilm can be used for the treatment of nitrates in wastewater [125] and biodegradation of the organic matter present in nature [126]. This biodegradation effort can be accelerated by designing a barrier material according to the concentration of the contaminant and the composition of the contaminant (mixed contaminant). The biodegradation process can be stimulated by providing added nutrients, electron acceptors and donors, or by providing a biocatalyst [51], which results in the development of biofilm on the surface of the contaminant via the natively present microbial species. If the existence of a required microorganism is lacking at the site of a contaminant, then the contaminant can be placed at a site where biofilm already exists. Alternatively, biofilm can be useful for the remediation of the toxic chemicals. Ultimately, a less harmful product can be formed by microbial biotransformation in nature due to the production of glycoconjugates without engineering the microorganism [113, 127].

Generally, the ex-situ bioremediation process is performed in a bioreactor due to the unavailability of suitable microorganisms and the unfavorable conditions at a contaminated site. In bioreactors, biofilms are added as inert support and used for the biochemical conversion of pollutants by sorption, particularly heavy metals, hydrocarbons, industrial waste, and wastewater treatment [128-130]. Biofilm-based bioreactors have many advantages over conventional treatment methods. For example, a high concentration of pollutants can be treated for a longer period of time, the volumetric capacity of biodegradation is enhanced, and the tolerance for highly toxic xenobiotics is increased, thereby supporting anaerobic and aerobic metabolism together and reducing environmental interference. Industrial biofilm reactors are generally set up under special conditions, such as when freely floating microorganisms are unable to produce adequate biomass or the microbial biomass cannot be retained for a long enough time to convert the toxic pollutants to environmentally acceptable forms [130] (Fig. 4).

Bacterial and fungal biofilm is a special type of biofilm where the bacterial cell is attached to fungal hyphae. Fungal hyphae provide nutrients, increase the bioavailability to the bacterial cell, and enhance the rate of consumption of nutrients via competition. This enables the bacteria to search for nutrient by travelling through the fungal hyphae. Phenanthrene, a polyaromatic hydrocarbon of fused benzene rings, is associated with soil contamination. This compound is degraded by Pseudomonas putida

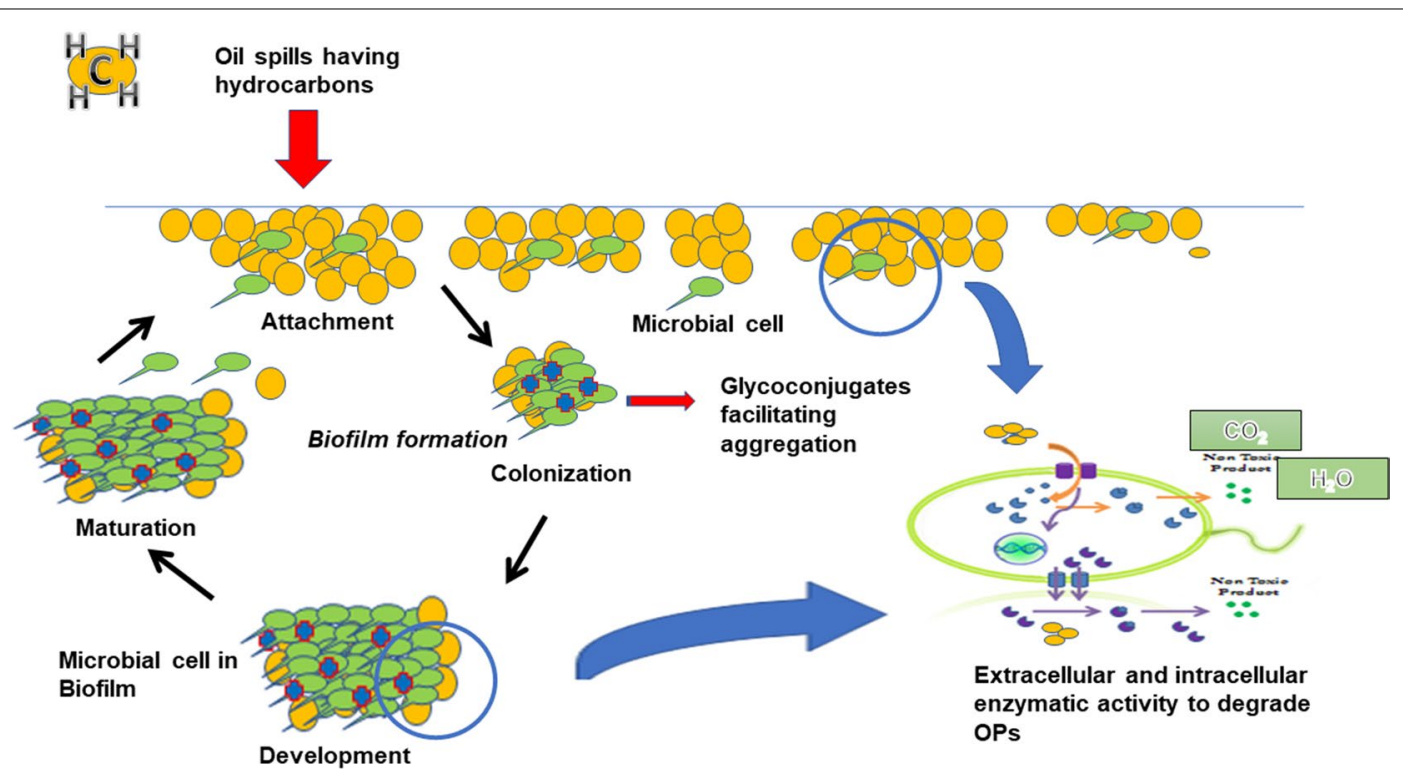

Fig. 4 Mechanism of oil spill hydrocarbon degradation using microbial glycoconjugates 
PpG7 in the presence of Pythium ultimum fungal mycelia [131]. The previous researcher confirmed the importance of microbial glycoconjugates in biofilm formation and degradation of the OPs.

\section{Glycoconjugates in pesticide degradation}

Pesticides are organic compounds used in an enormous quantity in agriculture and homes to control a broad spectrum of pests [132, 133]. Most pesticides are hydrophobic with complex structures. Due to the large amounts of pesticides entering into soil and water systems, these molecules become attached to soil particles and are not available for microbial activities [134-139]. The attachment of pesticides to soil particles is dependent on the physical and chemical properties of the soil and pesticides [140]. Presently, various categories of pesticides are being sold in the market, such as organophosphates, organochlorines, and pyrethroids. The biodegradation of these pesticides is an intricate process due to their low water solubility and poor bioavailability. Microbial glycoconjugates play an important role in the desorption of pesticide molecules from soil particles. These glycoconjugate biosurfactant molecules decrease surface tension and enhance the degradation via microbial metabolism [33, 141]. Such types of microbial glycoconjugates are surface-active amphipathic emulsifying molecules that have the capacity to enhance the partitioning of hydrophobic pesticides to the aqueous phase by producing emulsions at and above their critical micellar concentration (CMC) (Fig. 5). This enhances the bioavailability of pesticides to their potential degraders and can thus play a crucial role in overcoming the above problems [142].

Microorganisms in the soil produce several types of glycoconjugates that induce emulsification of the contaminant and increase water solubility. The water solubility of pesticides is linked to their bioavailable fractions. The bioavailable fraction is used by microbial cells during metabolic activity [143, 144]. The glycoconjugate enhances pesticide degradation by reducing surface tension, modifying hydrophobicity, and enhancing bioavailability [145]. The glycoconjugates are reported to increase the solubility of the pesticides in soil and promote their degradation [146]. Due to the beneficial properties of the glycoconjugate, they are acceptable for use in contaminated sites [147]. Rhamnolipids, fructose lipids, sophorolipids, and glycolipopeptides are commonly investigated for pesticide bioremediation. In the last decade glycoconjugates, have emerged as a facilitator of pesticide degradation under various conditions $[46,148$, 149]. We outline the major findings of glycoconjugates in the bioremediation of pesticides in Table 3 .
The addition of a glycoconjugate, an increased (30\%) biodegradation of endosulfan isomers by $B$. subtilis MTCC 1427 in both soil and liquids was reported in a previous study [23]. The enhanced mobilization and bioavailability of endosulfan isomers in the presence of the glycoconjugate was also reported and may be attributed to the enhanced solubilization of pesticides or the increased affinity towards microbial cells. The soil spiked with endosulfan showed enhanced degradation after 7 days of the experiment due to the production of rhamnolipids by $P$. aeruginosa [49]. A crude extract of a glycoconjugate (an anionic glycolipid) was produced by the Pseudomonas sp. B0406 strain and aided in the solubilization of endosulfan [154]. The Lysinibacillus sphaericus strain IITR51 was investigated as a way to produce a thermostable rhamnolipid glycoconjugate with the ability to enhance the solubility of the highly hydrophobic pesticide hexachlorocyclohexane $(\mathrm{HCH})$ and endosulfan [155]. Bioaugmentation with the glycoconjugate-producing bacteria also proved to be an efficient technique for the remediation of pesticides. The $\alpha$ and $\beta$ isomers of the endosulfan degraded by up to $82 \%$ in the presence of glycocnjugates having biosurfactant properties [151, 152].

The bioavailable fractions of the lindane are poor in the environment, which hinders degradation via microbial actions. Lindane contains six chlorine atoms, which make it more persistent. The Pseudomonas $\mathrm{Ptm}^{+}$strain was found to be a potent culture for the degradation of lindane in the environment along with the production of glycoconjugate. The production of the glycoconjugate was monitored in a minimal salt medium during lindane degradation. The produced glycoconjugate emulsified the organochlorine lindane to a greater extent than the other OPs [160]. A 95\% biodegradation rate was reported for lindane isomers by Sphingomonas sp. NM05 after the addition of rhamnolipids produced by Pseudomonas aeruginosa [156]. The impact of biosurfactants such as rhamnolipid, sophorolipid, and trehalose-containing lipid on the solubilization and biodegradation of $\mathrm{HCH}$, and their isomers in soil were also studied [156]. It was observed that sophorolipids promote a higher degradation of $\mathrm{HCH}$. The increased biodegradation of lindane $(700 \mathrm{mg} / \mathrm{L})$ by Pseudozyma VITJzN01 was demonstrated by a 3-9-fold increase in the solubilization of lindane isomers and was investigated with the addition of mannosylerythritol lipid bio-microemulsion [158]. Increased solubilization of lindane from 5 to $28 \mathrm{mg} \mathrm{L}^{-1}$ was reported under an increasing concentration of rhamnolipids from 0 to $1000 \mathrm{mg} \mathrm{L}^{-1}$ [144]. The trehalolipid produced by the Rhodococcus sp. strain IITR03 was isolated and characterized from the pesticide-contaminated sites [55]. Similarly, the effect of the rhamnolipid produced by Arthrobacter globiformis was investigated in the bioremediation of 

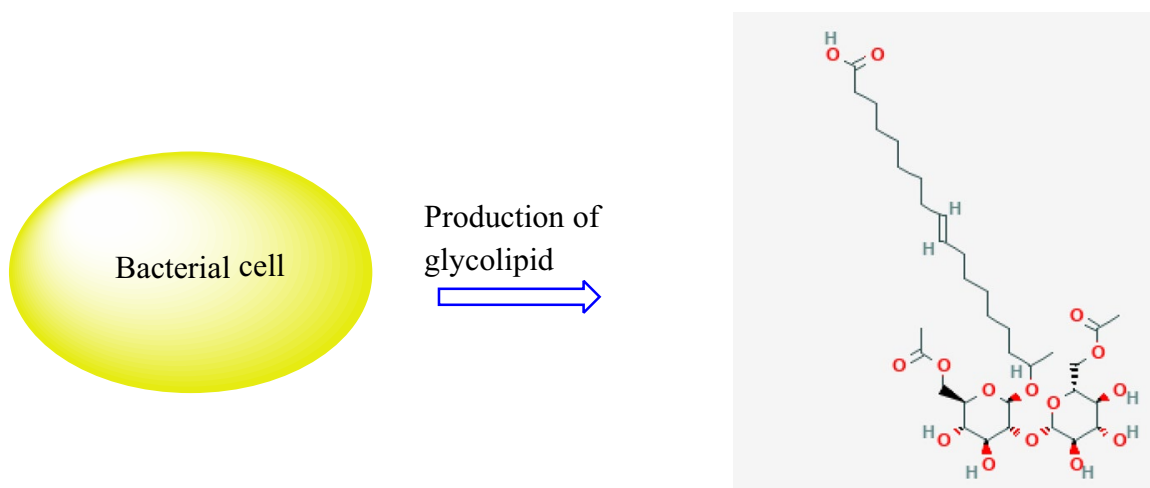

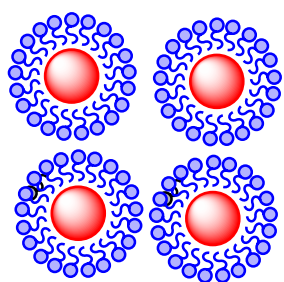

Formation of micelles
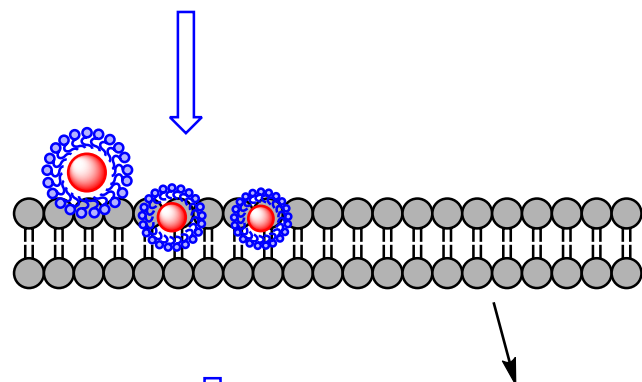

Desorption of the organic pollutants
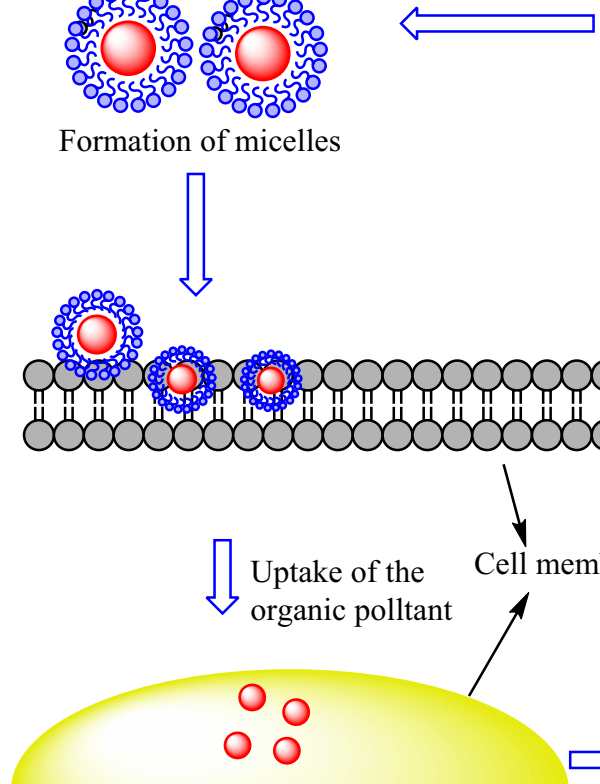

Cytosol
Sophorolipid

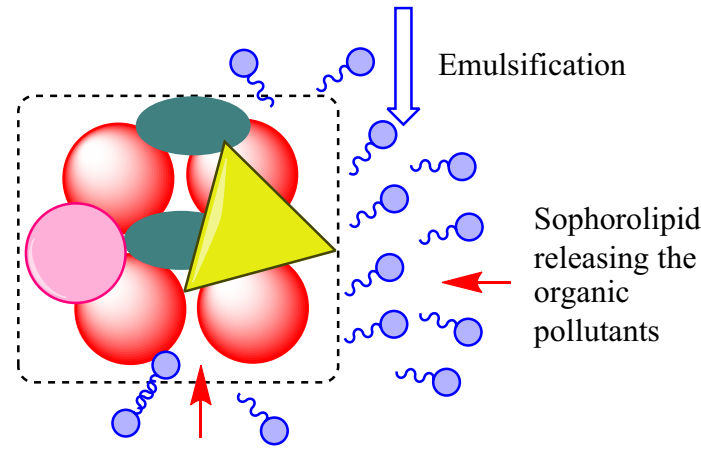

Organic pollutants attached with soil particles
Bioremediation of the toxic pollutants using bacterial metabolism

Fig. 5 Microbial glycoconjugates facilitate organic pollutant degradation via micelle formation

dichlorodiphenyl trichloroethane (DDT) [150]. Rhamnolipid enhanced the DDT degradation rate from 52 to $64 \%$. Pseudomonas sp. SB was able to produce a biosurfactant that promotes DDT degradation in combination with plant-microbe interactions [152]. The synergistic effects of mixed cultures of the white-rot fungus, Pleurotus ostreatus, and the biosurfactant-producing bacteria
Pseudomonas aeruginosa and Bacillus subtilis on DDT biodegradation were investigated and found to enhance DDT degradation [151]. There are many ways to remediate contaminated soil with microbial treatments and other methods. Some of the most commonly applied methods include soil washing, vapor extraction, desorption, microbial consortium, and phytoremediation. 
Table 3 Biosurfactant mediated bioremediation of soils contaminated with pesticides

\begin{tabular}{|c|c|c|c|c|}
\hline Pesticides & Concentration of pesticide & $\begin{array}{l}\text { Biosurfactant/biosurfactant producing } \\
\text { microbes }\end{array}$ & Degradation (\%) & References \\
\hline \multicolumn{5}{|l|}{ Organochlorines } \\
\hline Dichlorodiphenyl trichloroethane (DDT) & $282 \mu \mathrm{M}$ & Trehalolipid from Rhodococcus sp. IITR03 & $50-60$ & {$[55]$} \\
\hline DDT & $1.417 \mathrm{mg} / \mathrm{L}$ & Pseudomonas sp. SB + Grass sp. & 65.6 & {$[150]$} \\
\hline DDT & $0.0474 \mathrm{mg} / \mathrm{L}$ & $\begin{array}{l}\text { Rhamnolipids from Arthrobacter globi- } \\
\text { formis }\end{array}$ & 64.3 & [150] \\
\hline DDT & $0.25 \mu \mathrm{M}$ & $\begin{array}{l}\text { White rot fungi + biosurfactant from } \\
\text { Pseudomonas aeruginosa and Bacillus } \\
\text { subtilis }\end{array}$ & $\approx 86$ & {$[151]$} \\
\hline$a$-Endosulfan & $200 \mathrm{mg} / \mathrm{L}$ & Bacillus subtilis MTCC 1427 & 100 & {$[21]$} \\
\hline Endosulfan soil & $320 \mathrm{mg} / \mathrm{L}$ & Pseudomonas aeruginosa + rhamnolipid & $>90$ & [149] \\
\hline$\alpha$ - and $\beta$-endosulfan & $50 \mathrm{mg} / \mathrm{L}$ & Arthrobacter sp. ES-47 & $76.3-81.8$ & [152] \\
\hline$\alpha$ - and $\beta$-endosulfan & $50 \mathrm{mg} / \mathrm{L}$ & Bordetella petrii I GV 34 \& GV36 & $82-89$ & [153] \\
\hline a-Endosulfan & $1420-3400 \mathrm{mg} / \mathrm{L}$ & $\begin{array}{l}\text { Consortium of Bordetella petrii } \\
\text { | GV } 34 \text { and Bordetella petrii || GV } 36\end{array}$ & 100 & [153] \\
\hline$\beta$-Endosulfan & $1280-3100 \mathrm{mg} / \mathrm{L}$ & Achromobacter xylosoxidans GV 47 & 100 & [153] \\
\hline Endosulfan & $0.92 \mathrm{mg} / \mathrm{L}$ & Glycolipid, from Pseudomonas sp. B0406 & Increased solubility & [154] \\
\hline $\begin{array}{l}\text { Endosulfan and hexachlorocyclohexane } \\
\text { (HCH) }\end{array}$ & $\begin{array}{l}50 \mathrm{mg} / \mathrm{L} \text { (endosulfan), } \\
100 \mathrm{mg} / \mathrm{L}(\mathrm{HCH})\end{array}$ & $\begin{array}{l}\text { Rhamnolipid from Lysinibacillus sphaeri- } \\
\text { cus IITR51 }\end{array}$ & Increased solubility & [155] \\
\hline $\mathrm{HCH}$ & $40 \mathrm{mg} / \mathrm{L}$ & $\begin{array}{l}\text { Rhamnolipid from Pseudomonas aerugi- } \\
\text { nosa + Sphingomonas sp. NM05 }\end{array}$ & 95 & [156] \\
\hline $\mathrm{HCH}$ & $65 \mathrm{mg} / \mathrm{L}$ & $\begin{array}{l}\text { Cytisus striatus plantation + Rhodococcus } \\
\text { erythropolis ET54b }\end{array}$ & 33 & [157] \\
\hline $\mathrm{HCH}$ & $700 \mathrm{mg} / \mathrm{L}$ & Pseudozyma VITJzN01 & $\begin{array}{l}\text { 3-9-fold increase in } \\
\text { solubilization }\end{array}$ & [158] \\
\hline $\mathrm{HCH}$ & - & Rhamnolipids & Increase solubility & [159] \\
\hline \multicolumn{5}{|l|}{ Organophosphates } \\
\hline Methyl Parathion & - & Glycolipid from Pseudomonas sp. B0406 & Increased solubility & [154] \\
\hline Chlorpyrifos & $10 \mathrm{mg} / \mathrm{L}$ & Pseudomonas sp. ChID + biosurfactant & $>98$ & {$[20,143]$} \\
\hline Methyl parathion and ethyl parathion & $500 \mathrm{mg} / \mathrm{L}$ & $\begin{array}{l}\text { Glycolipid from Burkholderia cenocepacia } \\
\text { BSP3 }\end{array}$ & Increased solubility & [18] \\
\hline Quinalphos & $10,000 \mathrm{mg} / \mathrm{L}$ & $\begin{array}{l}\text { Biosurfactant from Pseudomonas aerugi- } \\
\text { nosa }\end{array}$ & 94 & [159] \\
\hline
\end{tabular}

Sodium dodecyl sulfate (SDS) and ethylene diamine tetra acetic acid (EDTA) were used to wash the soil with conventional methods. The combination of microbially produced citric acid and rhamnolipids is effective for the remediation of organochlorine pesticides from the soil [144]. Such microbial combinations are environmentally friendly and cost-effective and can help achieve environmental sustainability $[160,161]$.

The formation of stable emulsions was investigated using glycoconjugate produced by Bacillus strains and fenthion [26]. An anionic glycolipid produced by the Pseudomonas sp. B0406 strain was reported to aid in the solubilization of methyl parathion [154]. The complete degradation of chlorpyrifos $(10 \mathrm{mg} / \mathrm{L})$ was reported within 2 days of using Pseudomonas sp. supplemented with a glycoconjugate [21]. A $>10$ times increase in the aqueous-phase solubility of chlorpyrifos was reported with the addition of a biosurfactant produced by Pseudomonas sp. [143]. The glycolipid from Burkholderia cenocepacia BSP3 isolated from oilcontaminated soil was proposed to possess the ability to bioremediate the pesticides methyl parathion and ethyl parathion [18]. It was observed that Pseudomonas aeruginosa produces a glycoconjugate that enhances the solubilization of quinalphos [159].

The glycoconjugate from Pseudomonas cepacia aided in degrading the hydrophobic herbicide 2,4,5-trichlorophenoxyaceticacid [162]. Similarly, a higher biodegradation of carbendazim was reported by adding rhamnolipid to Rhodococcus sp. D-1 [54]. Approximately $24-35 \%$ biodegradation of trifluralin in the soil was reported after the addition of rhamnolipid [163]. The surfactin lipopeptide was produced by marine Bacillus velezensis MHNK1 under atrazine biodegradation. The complete degradation of atrazine was observed within 4 days after employing a combination 
of B. velezensis MHNK1 (2\%) and surfactin (2 CMC) [164].

\section{Glycoconjugates in wastewater treatment}

Microbial glycoconjugates have emerged as a tool to clean wastewater contaminated with organic pollutants. Various microbial approaches are used for the bioremediation of wastewater, but glycoconjugates are gaining more attention. The activated sludge process is popular for wastewater treatment. This process is based on the aerobic digestion of the microbial strains that produce flocs (floc-forming microbes) [165]. These flocs are formed by the network of extracellular polymeric substances (EPSs) produced by microbes [166]. Bacterial strains have been reported for glycoconjugate production which consists of carbohydrates, proteins, humic substances, uronic acids, lipid compounds, and nucleic acids. Enzymes play an important role in the hydrolysis of sludge [167]. These enzymes help to release EPSs and identify polysaccharides and glycoconjugates together with a lectin panel $[165,168]$.

Effective glycoconjugates can reduce the surface tension of water from 72 to $25 \mathrm{mN} / \mathrm{m}$ and the interfacial tension between polar and non-polar liquids for water against $\mathrm{n}$-hexadecane from 40 to $1 \mathrm{mN} / \mathrm{m}[169,170]$. Thus, glycoconjugates can also be used for the treatment of wastewater [171]. In a previous report, the enhanced removal of hydrocarbons was described using rhamnolipids, which was mainly attributed to improved solubility and reduced interfacial tension [172]. Microbial rhamnolipids are also described as efficient candidates for the pretreatment of waste activated sludge and contribute to the process of wastewater treatment [173]. Rhodococcus sp. PML026, a marine bacterial strain, was utilized for the production of glycoconjugate characterized as trehalolipids, exerted biosurfactant activity under diverse experimental conditions, and was proven to be an efficient candidate for wastewater treatment and other bioremediation purposes [174]. The various bacterial isolates for glycoconjugates were investigated by their biosurfactant producing abilities. These isolates have the potential to reduce the surface tension in the liquid medium from $71.1 \mathrm{mN} / \mathrm{m}$ to $32.1 \mathrm{mN} / \mathrm{m}$. The isolates were mainly belonging to the Aeromonadaceae, Bacillaceae, Enterobacteriaceae, Gordoniaceae, and Pseudomonadaceae families [175]. The wastewater bacterial strains showed antibiotic resistance and biofilm formation due to the production of biosurfactants. Low surface tension values of 28 and $36 \mathrm{mN} / \mathrm{m}$ were observed in the bacteria, which were not able to form a biofilm. This study showed that low surface tension can produce a weak biofilm, which can be correlated to the glycoconjugate playing a role in effective biofilm formation at polluted sites $[122,176]$.
Hollow membranous fibers also developed. These fibers supply the dissolved hydrogen to microbial population that stimulate the biodegradation of the chlorinated solvent present in groundwater [123]. Sophorolipids are another glycoconjugate biosurfactant utilized in oil spill management and the oil biodegradation of contaminated water [124]. Thus, microbial glycoconjugates are utilized in diverse forms for the treatment of wastewater, and the results obtained justify their candidacy for this purpose $[97,177,178]$.

\section{Conclusions and future prospects}

Microbial glycoconjugates are important for bioremediation purposes, and several investigations have confirmed the degradation-specific role of glycoconjugates. The glycoconjugates can be used for the broad bioremediation of pesticides, hydrocarbons, antibiotics, and several xenobiotics. Microbial glycoconjugates play a key role in the adhesion of cells in biofilms that increase the degradation efficiency for OPs. Thus, recent advances in the field of MG have added to the potential of glycoconjugates in different applications along with the management of OPs, which are an environmental nuisance due to their intense utilization in different anthropogenic activities. MG bears many unexplored horizons to be revealed and utilized in the development of efficient bioremediation procedures. Recent high-throughput omics-based techniques could be applied to explore the molecular basis of the glycoconjugate-based bioremediation of OPs.

\section{Acknowledgements \\ Authors acknowledge the grants from the Key-Area Research and Develop- ment Program of Guangdong Province, China (2018B020206001), China Postdoctoral Science Foundation (2020M672655), the National Natural \\ Science Foundation of China (31401763) and the Guangdong Special Branch Plan for Young Talent with Scientific and Technological Innovation, China (2017TQ04N026).}

\section{Authors' contributions}

PB collected all the relevant publications, arranged the general structure of the review, drafted the text and produced figures. AV, SG and GB revised the review. SC revised and formatted the manuscript. All authors read and approved the final manuscript.

\section{Availability of data and materials} Not applicable.

\section{Declarations}

Ethics approval and consent to participate Not applicable.

\section{Consent for publication}

Not applicable.

\section{Competing interests}

The authors declare that they have no competing interests. 


\begin{abstract}
Author details
${ }^{1}$ State Key Laboratory for Conservation and Utilization of Subtropical Agro-bioresources, Guangdong Laboratory for Lingnan Modern Agriculture, Integrative Microbiology Research Centre, South China Agricultural University, Guangzhou 510642, China. ${ }^{2}$ Guangdong Province Key Laboratory of Microbial Signals and Disease Control, South China Agricultural University, Guangzhou 510642, China. ${ }^{3}$ Department of Biochemistry, College of Basic Science and Humanities, SD Agricultural University, Gujarat 385506, India. ${ }^{4}$ School of Agriculture, Graphic Era Hill University, Bhimtal Campus, Dehradun, Uttarakhand 248002, India. ${ }^{5}$ Department of Biotechnology, Sardar Bhagwan Singh University, Dehradun, Uttarakhand 248161, India.
\end{abstract}

Received: 25 July 2020 Accepted: 27 February 2021

Published online: 18 March 2021

\section{References}

1. Bhatt P, Gangola S, Bhandari G, Zhang W, Maithani D, Mishra S, Chen S New insights into the degradation of synthetic pollutants in contaminated environments. Chemosphere. 2021;268:128827.

2. Chen T, Chang S. Potential microbial indicators for better bioremediation of an aquifer contaminated with vinyl chloride or 1,1-dichloroethene. Water Air Soil Pollut. 2020;231:239.

3. Bhatt P, Huang Y, Zhan H, Chen S. Insight into microbial applications for the biodegradation of pyrethroid insecticides. Front Microbiol. 2019;10:1778.

4. Yoshikawa M, Zhang M, Toyota K. Biodegradation of volatile organic compounds and their effects on biodegradability under co-existing conditions. Microbes Environ. 2017;32:188-200.

5. Mishra S, Lin Z, Pang S, Zhang W, Bhatt P, Chen S. Recent advanced technologies for the characterization of xenobiotic-degrading microorganisms and microbial communities. Front Bioeng Biotechnol. 2021;9:632059.

6. Yair S, Ofer B, Arik E, Shai S, Yossi R, Tzvika D, Amir K. Organophosphate degrading microorganisms and enzymes as biocatalysts in environmental and personal decontamination applications. Crit Rev Biotechnol. 2008;28:265-75.

7. Liston SD, Mann E, Whitfield C. Glycolipid substrates for ABC transporters required for the assembly of bacterial cell-envelope and cellsurface glycoconjugates. Biochim Biophys Acta Mol Cell Biol Lipids. 2017; 1862:1394-403.

8. Chong H, Li Q. Microbial production of rhamnolipids: Opportunities, challenges and strategies. Microb Cell Fact. 2017;16:137.

9. Patowary K, Patowary R, Kalita MC, Deka S. Characterization of biosurfactant produced during degradation of hydrocarbons using crude oil as sole source of carbon. Front Microbiol. 2017;8:279.

10. Sattin S, Berbadi A. Glycoconjugates and glycomimetics as microbial anti-adhesives. Trend Biotechnol. 2016;34:483-95.

11. Enaime G, Nettmann E, Berzio S, Bacaoui A, Yaacoubi A, Wichern M, Gehring T, Lubken M. Performance and microbial analysis during longterm anaerobic digestion of olive mill wastewater in a packed-bed biofilm reactor. J Chem Technol Biotech. 2020;95:850-61.

12. Messner P, Schaffer C, Kosma P. Bacterial cell envelope glycoconjugates. Adv Carbohyd Chem Biochem. 2013;69:209-72.

13. Tan YN, Li Q. Microbial production of rhamnolipids using sugars as carbon sources. Microb Cell Fact. 2018;17:89.

14. Zhou H, Huang X, Liang Y, Li Y, Xie Q, Zhang C, You S. Enhanced bioremediation of hydraulic fracturing flowback and produced water using an indigenous biosurfactant-producing bacteria Acinetobacter sp, Y2. Chem Eng J. 2020;397:125348.

15. Aguila-Torres P, Maldonado J, Gaete A, Figueroa J, González A, Miranda R, González-Stegmaier R, Martin C, González M. Biochemical and genomic characterization of the cypermethrin-degrading and biosurfactant-producing bacterial strains isolated from marine sediments of the Chilean Northern Patagonia. Mar Drugs. 2020;18:252.

16. Deng Z, Jiang Y, Chen K, Li J, Zheng C, Gao F, Liu X. One biosurfactant producing bacteria Achromobacter sp. A-8 and its potential use in microbial enhanced oil recovery and bioremediation. Front Microbiol. 2020;11:247.
17. Gupta B, Puri S, Thakur IS, Kaur J. Enhanced pyrene degradation by a biosurfactant producing Acinetobacter baumannii BJ5: Growth kinetics, toxicity and substrate inhibition studies. Environ Technol Innova. 2020;19:100804.

18. Wattanaphon HT, Kerdsin A, Thammacharoen C, Sangvanich P, Vangnai AS. A biosurfactant from Burkholderia cenocepacia BSP3 and its enhancement of pesticide solubilization. J Appl Microbiol. 2008;23:1365-2672.

19. Sharma S, Singh P, Raj M, Chadha BS, Saini HS. Aqueous phase partitioning of hexachlorocyclohexane $(\mathrm{HCH})$ isomers by biosurfactant produced by Pseudomonas aeruginosa WH-2. J Hazard Mater. 2009;171:1178-82.

20. Singh PB, Sharma S, Saini HS, Chadha BS. Biosurfactant production by Pseudomonas sp. and its role in aqueous phase partitioning and biodegradation of chlorpyrifos. Lett Appl Microbiol. 2009;49:378-83.

21. Awasthi N, Kumar A, Makkar R, Cameotra SS. Biodegradation of soilapplied endosulfan in the presence of a biosurfactant. J Environ Sci Heal B. 1999:34:793-803.

22. Onbasli D, Aslim B. Effects of some organic pollutants on the exopolysaccharides (EPSs) produced by some Pseudomonas spp. strains. J Hazard Mater. 2009;168:64-7.

23. Zhou MF, Yuan XZ, Zhong H, Liu ZF, Li H, Jiang LL, Zeng GM. Effect of biosurfactants on Laccase production and phenol biodegradation in solid-state fermentation. Appl Biochem Biotechnol. 2011;164:104-14.

24. Zhang C, Wang S, Yan Y. Isomerization and biodegradation of betacypermethrin by Pseudomonas aeruginosa $\mathrm{CH} 7$ with biosurfactant production. Bioresour Technol. 2011;102:7139-46.

25. Mnif I, Ghribi D. Glycolipid biosurfactants: main properties and potential applications in agriculture and food industry. J Sci Food Agric. 2016;96:4310-20.

26. Patel S, Homaei A, Patil S, Daverey A. Microbial biosurfactants for oil spill remediation: Pitfalls and potentials. Appl Microbiol Biotech. 2018;103:27-37.

27. Karlapudi AP, Venkateswarulu TS, Tammineedi J, Kanumuri L, Ravuru BK, Drisala VR, Kodali VP. Role of biosurfactants in bioremediation of oil pollution- a review. Petroleum. 2018;4:241-9.

28. Casullo de Araújo HW, Fukushima K, Takaki GMC. Prodigiosin production by Serratia marcescens UCP 1549 using renewable resources as a low-cost substrate. Molecules. 2010;15:6931-40.

29. Al-Bahry SN, Al-wahaibi YM, Elshafie AE, Al-Bemani AS, Joshi SJ, AlMakhmari HS, Al-Sulaimani HS. Biosurfactant production by Bacillus subtilis B20 using date molasses and its possible application in enhanced oil recovery. Int Biodeter Biodegr. 2012;81:141-6.

30. Jimoh AA, Lin J. Enhancement of Paenibacillus sp. D9 lipopeptide biosurfactant production through the optimization of medium composition and its application for biodegradation of hydrophobic pollutants. Appl Biochem Biotechnol. 2018;187:724-43.

31. Jimoh AA, Lin J. Biosurfactant. A new frontier for greener technology and environmental sustainability. Ecotoxicol Environ Saf. 2019;184:109607.

32. Lee DW, Lee H, Kwon BO, Khim JS, Yim UH, Kim BS, Kim JJ. Biosurfactant assisted bioremediation of crude oil of by indigenous bacteria isolated from Taean beach sediment. Environ Pollut. 2018;241:254-64.

33. Banat IM, Franzetti A, Gandolfi I, Bestetti G, Martinotti MG, Fracchia L, Smyth TJ, Marchant R. Microbial biosurfactants production, applications and future potential. Appl Microbiol Biotechnol. 2010;87:427-44.

34. Moya RI, Tsaousi K, Rudden M, Marchant R, Alameda EJ, Garcia RM, Banat IM. Rhamnolipid and surfactin production from olive oil mill waste as sole carbon source. Bioresour Technol. 2015;198:231-6.

35. Varjani SJ, Upasani VN. Core flood study for enhanced oil recovery through ex-situ bioaugmentation with thermo- and halo-tolerant rhamnolipid produced by Pseudomonas aeruginosa NCIM 5514. Bioresour Technol. 2016;220:175-82.

36. Varjani SJ, Rana DP, Jain AK, Bateja S, Upasani VN. Synergistic ex-situ biodegradation of crude oil by halotolerant bacterial consortium of indigenous strains isolated from on shore sites of Gujarat India. Bioresour Technol. 2015; 103: 116-124.

37. Soberon-Chavez G, Lepine F, Deziel E. Production of rhamnolipids Pseudomonas aeruginosa. Appl Microbiol Biotechnol. 2005;68:718-25. 
38. Varjani SJ, Upasani VN. Critical review on biosurfactant analysis, purification and characterization using rhamnolipid as a model biosurfactant. Bioresour Technol. 2017;232:389-97.

39. Jezierska S, Claus S, Van Bogaert I. Yeast glycolipid biosurfactants. FEBS Lett. 2018;592:1312-29.

40. Sun M, Ye M, Wu J, Feng Y, Shen F, Tian D, Liu K, Hu F, Li H, Jiang X, Yang $L$, Kengara FO. Impact of bioaccessible pyrene on the abundance of antibiotic resistance genes during Sphingobium sp.- and sophorolipidenhanced bioremediation in soil. J Hazard Mater. 2015:300:121-8.

41. Kosaric N. Biosurfactants and their application for soil bioremediation. Food Technol Biotechnol. 2001;39:295-304

42. Lai CC, Huang YC, Wei YH, Chang JS. Biosurfactant enhanced removal of total petroleum hydrocarbons from contaminated soil. J Hazard Mater. 2009;167:609-14.

43. Inakollu S, Hung H, Shreve GS. Biosurfactant enhancement of microbial degradation of various structural classes of hydrocarbon in mixed waste systems. Environ Eng Sci. 2004;21:463-9.

44. Whang LM, Liu PWG, Ma CC, Cheng SS. Application of rhamnolipid and surfactin for enhanced diesel biodegradation-effects of $\mathrm{pH}$ and ammonium addition. J Hazard Mater. 2009;164:1045-50.

45. Franzetti A, Caredda P, Ruggeri C, La Colla P, Tamburini E, Papacchini M, Bestetti G. Potential applications of surface-active compounds by Gordonia sp. strain BS29 in soil remediation technologies. Chemosphere. 2009;75:801-7.

46. Mata-Sandoval JC, Karns J, Torrents A. Effect of nutritional and environmental conditions on the production and composition of rhamnolipids by $P$. aeruginosa UG2. Microbiol Res. 2001;155:249-56.

47. Moldes AB, Paradelo R, Rubinos D, Devesa-Rey R, Cruz JM, Barral MT. Ex situ treatment of hydrocarbon-contaminated soil using biosurfactants from Lactobacillus pentosus. J Agric Food Chem. 2011;59:9443-7.

48. Sachdev DP, Cameotra SS. Biosurfactants in agriculture. Appl Microbiol Biotechnol. 2013;97:1005-16.

49. Karanth NGK, Deo PG, Veenanadig NK. Microbial productions of biosurfactants and their importance. Curr Sci. 1999;77:116-26.

50. Chrzanowski Ł, Wick LY, Meulenkamp R, Kaestner M, Heipieper HJ. Rhamnolipid biosurfactants decrease the toxicity of chlorinated phenols to Pseudomonas putida DOT-T1E. Lett Appl Microbiol. 2009:48:756-62.

51. Chrzanowski T, Owsianiak M, Szulc A, Marecik R, Piotrowska-Cyplik A, Olejnik-Schmidt AK, Staniewski J, Lisiecki P, Ciesielczyk F, Jesionowsk T, Heipieper HJ. Interactions between rhamnolipid biosurfactants and toxic chlorinated phenols enhance biodegradation of a model hydrocarbon-rich effluent. Int Biodeterior Biodegrad. 2011;65:605-11.

52. Sponza DT, Gok O. Effects of sludge retention time and biosurfactant on the treatment of polyaromatic hydrocarbon (PAH) in a petrochemical industry wastewater. Water Sci Technol. 2011;64:2282-92.

53. Alvarez A, Saez JM, Costa JSD, Colin VL, Fuentes MS, Cuozzo SA, Benimeli CS, Polti MA, Amoroso MJ. Actinobacteria: Current research and perspectives for bioremediation of pesticides and heavy metals. Chemosphere. 2017;166:41-62.

54. Bai N, Wang S, Abuduaini R, Zhang M, Zhu X, Zhao Y. Rhamnolipidaided biodegradation of carbendazim by Rhodococcus sp. D-1: Characteristics, products, and phytotoxicity. Sci Total Environ. 2017, 590: 343-351.

55. Bajaj A, Mayilraj S, Mudiam MKR, Patel DK, Manickam N. Isolation and functional analysis of a glycolipid producing Rhodococcus sp. strain IITR03 with potential for degradation of 1,1,1-trichloro-2,2-bis(4-chlorophenyl) ethane (DDT). Bioresour Technol. 2014;167:398-406.

56. Bodour AA, Drees KP, Maier RM. Distribution of biosurfactant producing bacteria in undisturbed and contaminated arid southwestern soils. Appl Environ Microbiol. 2003;69:3280-7.

57. dos Santos JJ, Moranho LT. Rhizospheric microorganisms as a solution for the recovery of soils contaminated by petroleum: A review. J Environ Manage. 2018;210:104-13.

58. Bordoloi NK, Konwar BK. Bacterial biosurfactant in enhancing solubility and metabolism of petroleum hydrocarbons. J Hazard Mater. 2009;170:495-505.

59. Whang LM, Liu PWG, Ma CC, Cheng SS. Application of biosurfactants, rhamnolipid, and surfactin, for enhanced biodegradation of dieselcontaminated water and soil. J Hazard Mater. 2008;151:155-63.
60. Vatsa P, Sanchez L, Clement C, Baillieul F, Dorey S. Rhamnolipid biosurfactants as new players in animal and plant defense against microbes. Int J Mol Sci. 2010;11:5095-108.

61. Lima TMS, Procópio LC, Brandão FD, Carvalho AMX, Tótola MR, Borges AC. Biodegradability of bacterial surfactants. Biodegradation. 2011;22:585-92.

62. Lawnicjak L, Marecik R, Chrzanonowski L. Contribution of biosurfactants to natural or induced bioremediation. Appl Microbiol Biotechnol. 2013:97:2327-39.

63. Chaprao MJ, da Silva RCFS, Rufino RD, Luna JM, Santos VA, Sarubbo LA. Production of a biosurfactant from Bacillus methylotrophicus UCP1616 for use in the bioremediation of oil-contaminated environments. Ecotoxicology. 2018;27:1310-22

64. Campos JM, Stamford TLM, Sarubbo LA, Luna JM, Rufino RD, Banat IM Microbial biosurfactants as additives for food industries. Biotechnol Prog. 2013;29:1097-108.

65. Santos DKF, Rufino RD, Luna JM, Santos VA, Sarubbo LA. Biosurfactants: Multifunctional biomolecules of the 21st century. Int J Mol Sci. 2016;17:1-31.

66. Almeida DG, Silva MGC, Barbosa RN, Silva DSP, Silva RO, Lima GMS, Gusmão NB, Sousa MFVQ. Biodegradation of marine fuel MF-380 by microbial consortium isolated from seawater near the petrochemical Suape Port, Brazil. Int Biodeterior Biodegrad. 2017;116:73-82.

67. Silva RCFS, Almeida DG, Rufino RD, Luna JM, Santos VA, Sarubbo LA. Applications of biosurfactants in the petroleum industry and the remediation of oil spills. Int J Mol Sci. 2014;15:12523-42.

68. Rocha e Silva NMP, Rufino RD, Luna JM, Santos VA, Sarubbo LA. Screening of Pseudomonas species for biosurfactant production using lowcost substrates. Biocatal Agric Biotechnol. 2014;3:132-9.

69. Silva SNRL, Farias CBB, Rufino RD, Luna JM, Sarubbo LA. Glycerol as substrate for the production of biosurfactant by Pseudomonas aeruginosa UCP0992. Colloids Surf B Biointerf. 2010;79:174-83.

70. Luna JM, Santos Filho AS, Rufino RD, Sarubbo LA. Production of biosurfactant from Candida bombicola URM 3718 for environmental applications. Chem Eng Trans. 2016;49:583-8.

71. Gusmão CAB, Rufino RD, Sarubbo LA. Laboratory production and characterization of a new biosurfactant from Candida glabrata UCP1002 cultivated in vegetable fat waste applied to the removal of hydrophobic contaminant. World J Microbiol Biotechnol. 2010;26:1683-92.

72. Almeida DG, Soares da Silva RCF, Luna JM, Rufino RD, Santos VA Sarubbo LA. Response surface methodology for optimizing the production of biosurfactant by Candida tropicalis on industrial waste substrates. Front Microbiol. 2017:8:157.

73. Rivera AD, Urbina MAM, Lopez VEL. Advances on research in the use of agro-industrial waste in biosurfactant production. World Microbiol Biotech. 2019;35:155.

74. Abbasi H, Hamedi MM, Lotfabad TB, Zahiri HS, Sharafi H, Masoomi F, Moosavi-Movahedi AA, Ortiz A, Amanlou M, Noghabi KA. Biosurfactantproducing bacterium, Pseudomonas aeruginosa MA01 isolated from spoiled apples: physicochemical and structural characteristics of isolated biosurfactant. J Biosci Bioeng. 2012;113:211-9.

75. Mahalingam NU, Sampath N. Isolation, characterization and identification of bacterial biosurfactant. Pela Res Lib. 2014;4:59-64.

76. Astuti DI, Purwasena IA, Putri RE, Amaniyah M, Sugai Y. Screening and characterization of biosurfactant produced by Pseudoxanthomonas sp. G3 and its applicability for enhanced oil recovery. J Petrol Explor Prod Technol. 2019:9:2279-89.

77. Golek P, Bednarski W, Brzozowski B. Dziuba B. The obtaining and properties of biosurfactants synthesized by bacteria of the genus Lactobacillus. Ann Microbiol. 2009:59:119-26.

78. Hu X, Wang C, Wang P. Optimization and characterization of biosurfactant production from marine Vibrio sp. strain 3B-2. Front Microbiol. 2015;6:976.

79. Elshafie AE, Joshi SJ, Al-Wahaibi YM, Al-Bemani AS, Al-Bahry SN, AlMaqbali D, Banat IM. Sophorolipids production by Candida bombicola ATCC 22214 and its potential application in microbial enhanced oil recovery. Front Microbiol. 2015;6:1324.

80. Liu Z, Tian X, Chen Y, Lin Y, Mohsin A, Chu J. Efficient sophorolipids production via a novel in situ separation technology by Starmerella bombicola. Proc Biochem. 2019;81:1-10. 
81. Bages-Estopa S, White DA, Winterburn JB, Webb C, Martina PJ. Production and separation of a trehalolipid biosurfactant. Biochem Engi. 2018;139:85-94

82. White DA, Hird LC, Ali ST. Production and characterization of a trehalolipid biosurfactant produced by the novel marine bacterium Rhodococcus sp., strain PML026. J Appl Microbiol. 2013;115:744-55.

83. Morita T, Ishibashi Y, Fukuoka T, et al. Production of glycolipid biosurfactants, cellobiose lipids, by Cryptococcus humicola JCM 1461 and their interfacial properties. Biosci Biotechnol Biochem. 2011;75:1597-9.

84. Santos A, Silva M, Costa E, Rufino RD, Santos VA, Ramos CS, Sarubbo LA, Porto A. Production and characterization of a biosurfactant produced by Streptomyces sp. DPUA 1559 isolated from lichens of the Amazon region. Braz Med Biol Res. 2017;51:e6657.

85. Ibrahim HMM. Characterization of biosurfactants produced by novel strains of Ochrobactrum anthropi HM-1 and Citrobacter freundii HM-2 from used engine oil-contaminated soil. Egypt Petroliu. 2018;27:21-9.

86. Ruangprachaya F, Chuenchomrat P. Isolation and characterization of biosurfactant produced by Lactic acid bacteria from indigenous Thai fermented foods. Int J Food Engi. 2018;4:268-72.

87. Shreve GS, Makula R. Characterization of a new rhamnolipid biosurfactant complex from Pseudomonas Isolate DYNA270. Biomolecules 2019;9:885.

88. Chakraborty S, Ghosh M, Chakraborti S, Jana S, Sen KK, Kokare C, Zhang L. Biosurfactant produced from Actinomycetes nocardiopsis A17: Characterization and its biological evaluation. Int J Biol Macromol. 2015;79:405-12.

89. Li J, Deng M, Wang Y, Chen W. Production and characteristics of biosurfactant produced by Bacillus pseudomycoides BS6 utilizing soybean oil waste. Int Biodeter Biodegrad. 2016;112:72-9.

90. Santos DKF, Resende AHM, de Almeida DG, da Silva RCFS, Rufino RD, Luna JM, Banat IM, Sarubbo LA. Candida lipolytica UCP0988 biosurfactant: Potential as a bioremediation agent and in formulating a commercial related product. Front Microbiol. 2017;8:767.

91. Jamal P, Nawawi W, Alam MZ. Optimum medium components for biosurfactant production by Klebsiella pneumoniae WMF02 utilizing sludge palm oil as a substrate. Aust J Basic Appl Sci. 2012;6:100-8.

92. Rahman K, Rahman TJ, McClean S, Marchant R, Banat IM. Rhamnolipid biosurfactant production by strains of Pseudomonas aeruginosa using low-cost raw materials. Biotechnol Prog. 2002;18:1277-81.

93. Vance-Harrop MH, Gusmao, NBd, Campos-Takak. GMd.New bioemulsifiers produced by Candida lipolytica using D-glucose and babassu oil as carbon sources. Braz J Microbiol. 2003;34:120-3.

94. Sobri IM, Halim M, Lai OM, Lajis AF, Yusof MT, Halmi MIE, Johari WLW, Wasoh H. Emulsification characteristics of rhamnolipids by Pseudomonas aeruginosa using coconut oil as carbon source. J Environ Microbiol Toxicol. 2018:6:7-12.

95. Araujo HWC, Andrade RFS, Montero-Rodriguez D, Rubio-Ribeaux D, Alves da Silva CA, Campos-Takaki GM. Sustainable biosurfactant produced by Serratia marcescens UCP 1549 and its suitability for agricultural and marine bioremediation applications. Microb Cell Fact. 2019;18:2.

96. Felix AKN, Martins JLL, Almeida JGL, Giro MEA, Cavalcante KF, Melo VMM, Pessoa ODL, Rocha MVP, Goncalves LRB, Aguiar RSS. Purification and characterization of a biosurfactant produced by Bacillus subtilis in cashew apple juice and its application in the remediation of oil contaminated soil. Colloid Surface B. 2019;175:256-63.

97. Saborimanesh N, Mulligan CN. Effect of sophorolipid biosurfactant on oil biodegradation by the natural oil-degrading bacteria on the weathered biodiesel, diesel and light crude oil. J Bioremed Biodeg. 2015;6:314

98. Zenati B, Chebbi A, Badis A, Eddouaouda K, Boutoumi H, El Hattab M, Hentati D, Chelbi M, Sayadi S, Chamkha M, Franzetti A. A non-toxic microbial surfactant from Marinobacter hydrocarbonoclasticus SdK644 for crude oil solubilization enhancement. Ecotoxicol Environ Saf. 2018;154:100-7.

99. Niu Y, Wu J, Wang W, Chen Q. Production and characterization of a new glycolipid, mannosylerythritol lipid, from waste cooking oil biotransformation by Pseudozyma aphidis ZJUDM34. Food Sci Nutr. 2019;7:937-48.

100. Mishra S, Zhang W, Lin Z, Pang S, Huang Y, Bhatt P, Chen S. Carbofuran toxicity and its microbial degradation in contaminated environments. Chemosphere. 2020;259:127429.
101. Huang Y, Zhang W, Pang S, Chen J, Bhatt P, Mishra S, Chen S. Insights into the microbial degradation and catalytic mechanisms of chlorpyrifos. Environ Res. 2021;194:110660.

102. Gaur N, Flora G, Yadav M, Tiwari A. A review with recent advancements on bioremediation-based abolition of heavy metals. Environ Sci-Proc Imp. 2014;16:180-93.

103. Gieg LM, Fowler SJ, Berdugo-Clavijo C. Syntrophic biodegradation of hydrocarbon contaminants. Curr Opin Biotech. 2014;27:21-9.

104. Horemans B, Breugelmans P, Hofkens J, Smolders E, Springael D. Environmental dissolved organic matter governs biofilm formation and subsequent linuron degradation activity of a linuron-degrading bacterial consortium. Appl Environ Microbiol. 2013;79:4534-42.

105. Pratt LA, Kolter R. Genetic analyses of bacterial biofilm formation. Curr Opinion Microbiol. 1999;2:598-603.

106. Lacal J, Reyes-Darias JA, García-Fontana C, Ramos JL, Krell T. Tactic responses to pollutants and their potential to increase biodegradation efficiency. J Appl Microbiol. 2013;114:923-33.

107. Field JA, Stams AJ, Kato M, Schraa G. Enhanced biodegradation of aromatic pollutants in cocultures of anaerobic and aerobic bacterial consortia. Anton Leeuw. 1995;67:47-77.

108. Kreft JU, Wimpenny JW. Effect of EPS on biofilm structure and function as revealed by an individual-based model of biofilm growth. Water Sci Technol. 2001;43:135-5.

109. Miqueleto AP, Dolosic CC, Pozzi E, Foresti E, Zaiat M. Influence of carbon sources and $\mathrm{C} / \mathrm{N}$ ratio on EPS production in anaerobic sequencing batch biofilm reactors for wastewater treatment. Bioresour Technol. 2010;101:1324-30.

110. Mah TFC, O'Toole GA. Mechanisms of biofilm resistance to antimicrobial agents. Trends Microbiol. 2001;9:34-9.

111. Sutherland IW. The biofilm matrix an immobilized but dynamic microbial environment. Trends Microbiol. 2001:9:222-7.

112. Latch DE, Packer JL, Arnold WA, McNeill K. Photochemical conversion of triclosan to 2, 8-dichlorodibenzo-p-dioxin in aqueous solution. J Photoch Photobio A. 2003;158:63-6.

113. Seo Y, Lee WH, Sorial G, Bishop PL. The application of a mulch biofilm barrier for surfactant enhanced polycyclic aromatic hydrocarbon bioremediation. Environ Pollut. 2009;157:95-101.

114. Wang Y, Oyaizu H. Enhanced remediation of dioxins-spiked soil by a plant-microbe system using a dibenzofuran-degrading Comamonas sp. and Trifolium repens L. Chemosphere. 2011;85:1109-14.

115. Donlan RM, Costerton JW. Biofilms: survival mechanisms of clinically relevant microorganisms. Clinical Microbiol Rev. 2002;15:167-93.

116. Fletcher M, Lessman JM, Loeb Gl. Bacterial surface adhesives and biofilm matrix polymers of marine and freshwater bacteria. Biofouling. 1991:4:29-34

117. Zhang W, Pang S, Lin Z, Mishra S, Bhatt P, Chen S. Biotransformation of perfluoroalkyl acid precursors from various environmental systems: Advances and perspectives. Environ Pollut. 2021;272:115908.

118. Singh R, Paul D, Jain RK. Biofilms: Implications in bioremediation. Trends Microbiol. 2006;14:390-7.

119. Simoes LC, Simoes M, Vieira MJ. Biofilms interactions between distinct bacterial genera isolated from drinking water. Appl Environ Microbiol. 2007:73:6192-200.

120. Katharios-Lanwermeyer S, Xi C, Jakubovics NS, Rickard AH. Mini-review: microbial coaggregation: ubiquity and implications for biofilm development. Biofouling. 2014;30:1235-51.

121. Bogino PC, De las Mercedes OM, Sorroche FG, Giordano W. The role of bacterial biofilms and surface components in plant-bacterial associations. Int J Mol Sci. 2013;14:15838-59.

122. Jaloweicki L, Zur J, Cojniak J, Ejhed H, Plaza G. Properties of antibioticresistant bacteria isolated from onsite wastewater treatment plant in relation to biofilm formation. Curr Microbiol. 2017;75:639-49.

123. Jorgensen KS, Salminen JM, Bjorklof K. Monitored natural attenuation. In: cummings SP, editor. Bioremediation: Methods and Protocols. Totowa: Human Press; 2010. pp. 217-33.

124. Vogt $\mathrm{C}$, Richnow HH. Bioremediation via in situ microbial degradation of organic pollutants. In: Geobiotechnology II. Berlin: Springer; 2013. pp. 123-46.

125. Williamson WM, Close ME, Leonard MM, Webber JB, Lin S. Groundwater biofilm dynamics grown in situ along a nutrient gradient. Groundwater. 2012:50:690-703. 
126. Långmark J, Storey MV, Ashbolt NJ, Stenström TA. Artificial groundwater treatment: Biofilm activity and organic carbon removal performance. Water Res. 2004;38:740-8.

127. Payne RB, May HD, Sowers KR. Enhanced reductive dechlorination of polychlorinated biphenyl impacted sediment by bioaugmentation with a dehalorespiring bacterium. Environ Sci Technol. 2011;45:8772-9.

128. Bryers JD. Bacterial biofilms. Curr Opinion Biotechnol. 1993;4:197-204.

129. Boon N, De Gelder L, Lievens H, Siciliano SD, Top EM, Verstraete W. Bioaugmenting bioreactors for the continuous removal of 3-chloroaniline by a slow release approach. Environ Sci Technol. 2002;36:4698-704.

130. Qureshi N, Annous BA, Ezeji TC, Karcher P, Maddox IS. Biofilm reactors for industrial bioconversion processes: Employing potential of enhanced reaction rates. Microb Cell Fact. 2005;4:24.

131. Day SM. US environmental regulations and policies their impact on the commercial development of bioremediation. Trends Biotechnol. 1993;11:324-8.

132. Bhatt P, Pal K, Bhandari G, Barh A. Modeling of methyl halide biodegradation on bacteria and its effect on other environmental systems. Pest Biochem Physiol. 2019;158:88-100

133. Bhatt P, Gangola S, Chaudhary P, Khati P, Kumar G, Sharma A, Srivastava A. Pesticide induced up-regulation of esterase and aldehyde dehydrogenase in indigenous Bacillus spp. Bioremediat J. 2019;23:42-52.

134. Bustamante M, Duran N, Diez MC. Biosurfactants are useful tools for the bioremediation of contaminated soil: a review. J Soil Sci Plant Nutr. 2012:12:667-87.

135. Bhatt P, Huang Y, Rene ER, Kumar AJ, Chen S. Mechanism of allethrin biodegradation by a newly isolated Sphingomonas trueperi strain CW3 from wastewater sludge. Bioresour Technol. 2020;305:123074.

136. Bhatt $P$, Zhang W, Lin Z, Pang S, Huang Y, Chen S. Biodegradation of allethrin by a novel fungus Fusarium proliferatum strain CF2, isolated from contaminated soils. Microorganisms. 2020;8:593.

137. Bhatt $P$, Huang Y, Zhang W, Sharma A, Chen S. Binding interaction of glyphosate with glyphosate oxidoreductase and C-P lyase: Molecular docking and molecular dynamics simulation studies. J Hazard Mater 2021:409:124927.

138. Bhatt P, Zhou X, Huang Y, Zhang W, Chen S. Characterization of the role of esterases in the biodegradation of organophosphate, carbamate, and pyrethroid pesticides. J Hazard Mater. 2021:411:125026.

139. Bhatt P, Rene ER, Kumar AJ, Zhang W, Chen S. Binding interaction of allethrin with esterase: Bioremediation potential and mechanism. Bioresour Technol. 2020;310:123845.

140. Zhang W, Lin Z, Pang S, Bhatt P, Chen S. Insights into the biodegradation of lindane ( $\gamma$-hexacholocyclohexane) using a microbial system. Front Microbiol. 2020;11:522.

141. Singh A, Van Hamme JD, Ward OP. Surfactants in microbiology and biotechnology: Part 2. Application aspects. Biotechnol Adv. 2007;25:99-121.

142. Noordman WH, Janssen DB. Rhamnolipid stimulates uptake of hydrophobic compounds by Pseudomonas aeruginosa. Appl Environ Microbiol. 2002;68:4502-8

143. Singh P, Saini HS, Raj M. Rhamnolipid mediated enhanced degradation of chlorpyrifos by bacterial consortium in soil-water system. Ecotoxicol Environ Saf. 2016:134:156-62.

144. Feng $Y$, Huang $Y$, Zhan $H$, Bhatt $P$, Chen S. An overview of strobilurin fungicide degradation: Current status and future perspective. Front Microbiol. 2020;11:389.

145. Mohanty S, Mukherji S. Alteration in cell surface properties of Burkholderia spp. during surfactant-aided biodegradation of petroleum hydrocarbons. Appl Microbiol Biotechnol. 2012;94:193-204.

146. Mata-Sandoval JC, Karns J, Torrents A. Influence of rhamnolipids and triton $\mathrm{X}-100$ on the desorption of pesticides from soils. Environ Sci Technol. 2002;36:4669-75.

147. Mulligan CN. Recent advances in the environmental applications of biosurfactants. J Colloid Inter Sci. 2009;14:372-8.

148. Guo Q, Yan J, Wen J, Hu Y, Chen Y, Wu W. Rhamnolipid-enhanced aerobic biodegradation of triclosan (TCS) by indigenous microorganisms in water-sediment systems. Sci Total Environ. 2016;571:1304-11.

149. Mani KA, Hamid SS, Ramalingam S, Kaliamoorthi R. Effect of rhamnolipid potential on biodegradation of endosulfan by Pseudomonas aeruginosa in batch studies. J Biosci Technol. 2011;2:268-78.
150. Wang B, Wang Q, Liu W, Liu X, Hou J, Teng Y, Luo Y, Christie P. Biosurfactant-producing microorganism Pseudomonas sp. SB assists the phytoremediation of DDT-contaminated soil by two grass species. Chemosphere. 2017;182:137-42.

151. Purnomo AS, Ashari K, Hermansyah FT. Evaluation of the synergistic effect of mixed cultures of white-rot fungus Pleurotus ostreatus and biosurfactant-producing bacteria on DDT biodegradation. J Microbiol Biotechnol. 2017;27:1306-15.

152. Odukkathil G, Vasudevan N. Biodegradation of endosulfan isomers and its metabolite endosulfate by two biosurfactant producing bacterial strains of Bordetella petrii. J Environ Sci Health B. 2015;50:81-9.

153. Odukkathil G, Vasudevan N. Residues of endosulfan in surface and subsurface agricultural soil and its bioremediation. J Environ Manag. 2016;165:72-80.

154. Garcia Reyes S, Yanez Ocampo G, Wong Villarrealc A, Rajaretinam RK, Thavasimuthue C, Patiñof R, Ortiz Hernández ML. Partial characterization of a biosurfactant extracted from Pseudomonas sp. B0406 that enhances the solubility of pesticides. Environ Technol. 2017;39:2622-31.

155. Gaur VK, Bajaj A, Regar RK, Kamthan M, Jha RR, Srivastava JK, Manickam N. Rhamnolipid from a Lysinibacillus sphaericus strain IITR51 and its potential application for dissolution of hydrophobic pesticides. Bioresour Technol. 2018;272:19-25.

156. Manickam N, Bajaj A, Saini HS, Shanker R. Surfactant mediated enhanced biodegradation of hexachlorocyclohexane $(\mathrm{HCH})$ isomers by Sphingomonas sp. NM05. Biodegradation. 2012;23:673-82.

157. Bacerra-Castro C, Kidd PS, Rodriguez-Garrido B, Monterroso C, Santos-Ucha P, Prieto-Fernandez A. Phytoremediation of hexachlorocyclohexane $(\mathrm{HCH})$ contaminated soil using Cytisus striatus and bacterial inoculants in soil with distinct organic matter content. Environ Pollut. 2013;178:202-10

158. Abdul Salam J, Das N. Enhanced biodegradation of lindane using oil-in-water bio-microemulsion stabilized by biosurfactant produced by a new yeast strain, Pseudozyma VITJzN01. J Microbiol Biotechnol. 2013;23:1598-609.

159. Nair AM, Rebello S, Rishad KS, Asok AK, Jisha MS. Biosurfactant facilitated biodegradation of quinalphos at high concentrations by Pseudomonas aeruginosa Q10. Soil Sedim Contam Int J. 2015;24:542-53.

160. Anu Appaiah KA, Karanth NGK. Insecticide specific emulsifier production by hexachlorocyclohexane utilizing Pseudomonas tralucida Ptm ${ }^{+}$ strain. Biotechnol Lett. 1991:13:371374.

161. Bhatt P, Verma A, Verma S, Anwar MS, Prasher P, Mudila H, Chen S. Understanding phytomicrobiome: A potential reservoir for better crop management. Sustainability. 2020;12:5446.

162. Banerjee S, Duttagupta S, Chakrabarty AM. Production of emulsifying agent during growth of Pseudomonas cepacia with 2,4,5-trichlorophenoxyacetic acid. Arch Microbiol. 1983;135:110114.

163. Zenginyurek $O$. Effects of biosurfactants on remediation of soils contaminated with pesticides. Master's thesis, Izmir Institute of Technology. 2002.

164. Jakinala P, Lingampally N, Kyama A, Hameeda B. Enhancement of atrazine biodegradation by marine isolate Bacillus velezensis MHNK1 in presence of surfactin lipopeptide. Ecotoxicol Environ Saf. 2019;182:109372.

165. Wawrzynczyk J, Szewczyka E, Norrlow O, Szwajcer Dey E. Application of enzymes, sodium tripolyphosphate and cation exchange resin for the release of extracellular polymeric substances from sewage sludge characterization of the extracted polysaccharides/glycoconjugates by a panel of lectins. J Biotech. 2007;130:274-81.

166. Liu Y, Fang HHP. Influences of extracellular polymeric substances (EPS) on flocculation, settling, and dewatering of activated sludge. Crit Rev Environ Sci Technol. 2003;33:237-73.

167. Sesay ML, Ozcengiz G, Sanin FD. Enzymatic extraction of activated sludge extracellular polymers and implications on bioflocculation. Water Res. 2006:40:1359-66.

168. Dey ES, Szewczyk E, Wawrzynczyk J, Norrlow O. A novel approach for characterization of exopolymeric material in sewage sludge. J Res Sci Technol. 2006:3:97-103.

169. Mulligan CN. Environmental Applications for Biosurfactants. Environ Pollut. 2005:133:183-98

170. Soberón-Chávez G, Maier RM. Biosurfactants: a General Overview. In: Soberón-Chávez G, editor. Biosurfactants. Berlin: Springer-Verlag; 2011. pp. 1-11. 
171. Akbari S, Abdurahman NH, Yunus RM, Fayaz F, Alara OR. Biosurfactants-a new frontier for social and environmental safety: A mini review. Biotech Res Inno. 2018;2:81-90.

172. Zhang HZ, Long XW, Sha RY, Zhang GL, Meng Q. Biotreatment of oily wastewater by rhamnolipids in aerated active sludge system. J Zhejiang Univ Sci B. 2009;10:852-9.

173. Li JQ, Liu WZ, Cai WW, Wang B, Ajibade FO, Zhang ZJ, Tiang XD, Wang AJ. Applying rhamnolipid to enhance hydrolysis and acidogenesis of waste activated sludge: Retarded methanogenic community evolution and methane production. RSC Adv. 2019;9:2034e2041.

174. White D, Hird L, Ali S. Production and characterization of a trehalolipid biosurfactant produced by the novel marine bacterium Rhodococcus sp., strain PML026. J Appl Microbiol. 2013;115:744-55.

175. Ndlovu T, Khan S, Khan W. Distribution and diversity of biosurfactantproducing bacteria in a wastewater treatment plant. Environ Sci Pollut Res. 2016;23:9993-10004.
176. Fang Y, Hozalski RM, Clapp LW, Novak PJ, Semmens MJ. Passive dissolution of hydrogen gas into groundwater using hollow-fiber membranes. Water Res. 2002;36:3533-42.

177. Bhatt P, Bhatt K, Sharma A, Zhang W, Mishra S, Chen S. Biotechnological basis of microbial consortia for the removal of pesticides from the environment. Crit Rev Biotechnol. 2021. doi:https://doi.org/10.1080/ 07388551.2020 .1853032

178. Thavasi R, Jayalakshmi S, Balasubramanian T, Banat IM. Biosurfactant production by Corynebacterium kutscheri from waste motor lubricant oil and peanut oil cake. Lett Appl Microbiol. 2007;45:686-91.

\section{Publisher's note}

Springer Nature remains neutral with regard to jurisdictional claims in published maps and institutional affiliations.
Ready to submit your research? Choose BMC and benefit from:

- fast, convenient online submission

- thorough peer review by experienced researchers in your field

- rapid publication on acceptance

- support for research data, including large and complex data types

- gold Open Access which fosters wider collaboration and increased citations

- maximum visibility for your research: over $100 \mathrm{M}$ website views per year

At BMC, research is always in progress.

Learn more biomedcentral.com/submissions 